
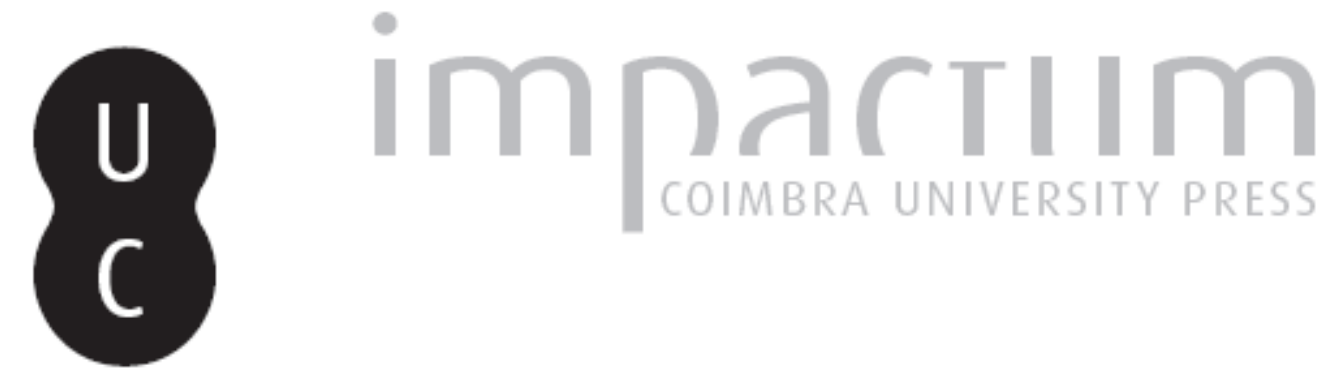

\title{
O acordo TRIPS na dinâmica do comércio internacional
}

\section{Autor(es): Coimbra, Marta}

Publicado por: Faculdade de Direito da Universidade de Coimbra

URL persistente:

URI:http://hdl.handle.net/10316.2/35531

DOI:

DOI:http://dx.doi.org/10.14195/0870-4260_56_6

Accessed : $\quad$ 26-Apr-2023 10:43:24

A navegação consulta e descarregamento dos títulos inseridos nas Bibliotecas Digitais UC Digitalis, UC Pombalina e UC Impactum, pressupõem a aceitação plena e sem reservas dos Termos e Condições de Uso destas Bibliotecas Digitais, disponíveis em https://digitalis.uc.pt/pt-pt/termos.

Conforme exposto nos referidos Termos e Condições de Uso, o descarregamento de títulos de acesso restrito requer uma licença válida de autorização devendo o utilizador aceder ao(s) documento(s) a partir de um endereço de IP da instituição detentora da supramencionada licença.

Ao utilizador é apenas permitido o descarregamento para uso pessoal, pelo que o emprego do(s) título(s) descarregado(s) para outro fim, designadamente comercial, carece de autorização do respetivo autor ou editor da obra.

Na medida em que todas as obras da UC Digitalis se encontram protegidas pelo Código do Direito de Autor e Direitos Conexos e demais legislação aplicável, toda a cópia, parcial ou total, deste documento, nos casos em que é legalmente admitida, deverá conter ou fazer-se acompanhar por este aviso.

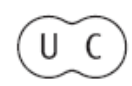




\section{UNIVERSIDADE DE COIMBRA}

FACULDADE DE DIREITO

\section{BOLETII DE CIÊECIAS ECONÓMICAS}

VOLUME LVI

$\begin{array}{llll}2 & 0 & 1 & 3\end{array}$

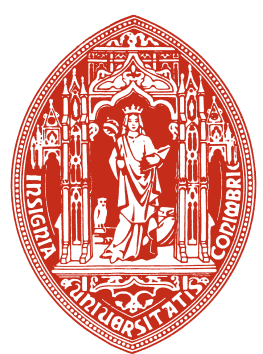

COIMBRA 


\section{O ACORDO TRIPS NA DINÂMICA DO COMÉRCIO INTERNACIONAL}

\section{Contextualização}

\subsection{Os direitos de propriedade intelectual}

"(...) o registo de marcas, a concessão de patentes de invenção ou a tutela dos direitos de autor geram verdadeiros monopólios de exploração de determinadas criações, que ficam reservadas em exclusivo ao seu titular, com exclusão de todas as outras pessoas. Não tinha de ser assim. E nem sempre foi assim. (...) E se o legislador julgou oportuno privar a sociedade desta margem de liberdade - ao atribuir direitos de carácter exclusivo -, fê-lo por considerar que a própria sociedade, como um todo, teria algo a ganhar com isso: o estímulo à criação artística ou técnica de que todos beneficiariam, (...) ou a ordenação da concorrência, mediante a identificação e distinção dos produtos ou serviços (...)"'.

Assim se definem os direitos de propriedade intelectual': são direitos exclusivos de utilização de certos bens imateriais, com o propósito último de constituírem um instrumento de

1 Silva, Pedro Sousa e, Direito Industrial, p. 9 e 10.

2 Note-se que utilizamos o conceito num sentido amplo, por forma a abranger tanto os direitos de propriedade intelectual em sentido estrito (direitos de autor), como os direitos de propriedade industrial. 
tutela da inovação e incentivo da criatividade (no caso dos direitos de autor, das patentes, dos modelos de utilidade...), ou de se tornarem mecanismos distintivos promotores da concorrência empresarial (no caso das marcas, logótipos, indicações geográficas...). São direitos de conteúdo negativo, na medida em que se consubstanciam na faculdade de proibir terceiros de fazer uso de determinado sinal ou de exercer certa actividade. São privilégios concedidos pelo poder público ao seu titular, que constituem monopólios de exploração ou de uso.

\subsection{Os DPI no plano internacional: a situação pré-TRIPS}

A consideração da protecção dos DPI à escala global não constitui uma realidade recente. De facto, desde a $2 .{ }^{a}$ metade do séc. XIX que a comunidade internacional, em consonância com o desenvolvimento constatado ao nível deste ramo do direito e com o aumento das relações entre países, tem mostrado preocupação em uniformizar regras neste domínio. Essa preocupação acabou por se reflectir na celebração de vários acordos internacionais ${ }^{3}$, a maioria dos quais administrados pela Organização Mundial de Propriedade Intelectual (OMPI) ${ }^{4}$, de entre os quais se destacam a

${ }^{3}$ Veja-se, a este propósito, a sistematização firmada por DutField, Graham e Suthersanen, Uma, Global Intellectual Property Law, p. 30 e 31, que distingue entre acordos que definem standards básicos de protecção com base num princípio de tratamento nacional, acordos que concedem protecção aos direitos em mais do que um país, e acordos de classificação e definição de conceitos.

${ }^{4}$ Cfr. Gonçalves, Luís Couto, A proteç̧ão da propriedade..., p. 369: "A Organização Mundial da Propriedade Intelectual, com sede em Genebra, Suíça, foi criada por uma convenção assinada em Estocolmo em 14-7-1967 e entrou em vigor em 1970. As origens da OMPI remontam a 1883 e a 1886, anos em que foram adoptadas, respectivamente, a Con- 
Convenção da União de Paris e a Convenção de Berna para a protecção das obras literárias e artísticas ${ }^{5}$.

Todavia, parece que, aos olhos de muitos, a protecção conferida aos DPI por via destes instrumentos não se mostrava suficiente. As razões dessa insuficiência prendiam-se, sobretudo, com o facto de os Tratados anteriores ao TRIPS se basearem numa ideia de territorialidade dos direitos (deixando a definição do escopo e conteúdo dos direitos entregue à arbitrariedade de cada Estado), e de praticamente não preverem standards mínimos de protecção ${ }^{6}$, nem uma harmonização entre os vários ordenamentos jurídicos. A isto se pode acrescentar a falta de mecanismos de aplicação efectiva dos direitos (pela inexistência de regras que contemplassem essa aplicação e pela ausência de sistemas obrigatórios de resolução de litígios) por parte da OMPI. Por outro lado, a intensidade com que o processo de globalização das economias se fazia sentir sobre o comércio (ao mesmo tempo que se vivia uma 'revolução tecnológica') vinha exigir a previsão de novas regras.

A conclusão a retirar deste contexto é vista com unanimidade pela doutrina: "Starting in 1970s, developed countries expressed increasing concern that the treaty system administered by

venção de Paris para a protecção da propriedade industrial (CUP) e a Convenção de Berna para a protecção das obras literárias e artísticas. As duas convenções previam, cada uma, o funcionamento de uma "Secretaria". A partir de 1893 as duas "Secretarias" fundiram-se nas denominadas "Secretarias Internacionais reunidas para a Protecção da Propriedade Intelectual" (BIRPI), com sede em Berna (Suíça), entidade que antecedeu a actual OMPI. Em 1960 as BIRPI transferiram-se para Genebra."

${ }^{5}$ Actualmente, a OMPI administra um total de 25 Tratados - informação disponível em <http://www.wipo.int/treaties/en>.

${ }^{6}$ A este propósito, ver, nomeadamente, Einhorn, Talia, The impact of the WTO Agreement on TRIPS on EC Law, p. 1070. 
WIPO failed to adequately protect the interests of their technology-based and expressive industries" ${ }^{\text {. }}$.

A verdade é que, pelo seu papel central nesta matéria, a OMPI e as Convenções por ela administradas continuam a merecer referência no TRIPS. Esta articulação entre os vários instrumentos de regulamentação internacional é reflectida em várias disposições, onde se aplica a técnica legislativa da remissão (veja-se, desde logo, o artigo $2 .^{\circ}$ do Acordo).

Optando por incorporar os textos internacionais que já existiam sobre a matéria, o TRIPS não deixa de lhe introduzir modificações, e prever a adopção de novas regras, muitas delas motivadas pela sujeição do Acordo aos princípios gerais da OMC. Isto acaba por fazer do TRIPS um acordo "cujo âmbito de aplicação (id est, direitos privativos abrangidos), conteúdo normativo (regime jurídico) e eficácia (aplicação efectiva) ultrapassam as convenções anteriormente celebradas" ${ }^{\prime}$.

\subsection{DPI e comércio?: a emergência do TRIPS}

O Acordo TRIPS foi concluído em 1994, na Uruguay Round do General Agreement on Trade and Tariffs (GATT), com vista a ser implementado através desta organização internacional.

$\mathrm{Na}$ medida em que o GATT foi originalmente concebido para estabelecer um quadro legal para o comércio

7 Cfr. Resource Book on TRIPS and development,..., p. 3.

Em confirmação desta ideia, veja-se também Bossche, Peter Van Den, The Law Policy..., p. 751: "Developed-country negotiators of the TRIPS Agreement viewed the existing WIPO conventions as inadequate to address the needs of their business sectors in the "post-industrial era" or "information age".

8 Almeida, Alberto Francisco Ribeiro, "Os princípios estruturantes do Acordo TRIPS's", p. 33. 
internacional de produtos, é aceitável que se questione em que medida se mostra legítima a sua intervenção em campos que extravasam o domínio das competências que lhe foram inicialmente atribuídas. Ou seja, pode perguntar-se se a propriedade intelectual é, afinal, um assunto suficientemente conexo com o comércio.

A relação entre os DPI e o comércio vem, desde logo, sustentada com base na necessidade de combater práticas comerciais abusivas ${ }^{9}$ que nascem da violação destes direitos: falamos da contrafacção e da pirataria ${ }^{10}$. Mas parte também da consciência de que a incorporação de DPI nos produtos comercializados lhes aumenta exponencialmente o valor económico no tráfico ${ }^{11}$.

${ }^{9}$ Veja-se Canotilho, J.J. Gomes e Machado, Jónatas, A questão da Constitucionalidade das Patentes "Pipeline", p. 47: "O relevo económico e social, à escala global, prende-se com o facto de os produtos com incorporação intensiva de informação, conhecimento e criação intelectual serem predominantemente produzidos nos países desenvolvidos e, em maior ou menor medida contrafeitos, sem sanções adequadas, nos Estados em vias de desenvolvimento, com enorme prejuízo, nomeadamente, para autores, inventores e editores".

${ }^{10}$ A este propósito, Trebilcock, Michael e Howse, Robert, The Regulation of International Trade, p. 397: "American business interests estimated losses in the billions of dollars annualy from these kinds of supposed inadequacies in intellectual property protection." Mas adianta-se de imediato: "From a trade theory perspective, however, it is far from clear that all countries should be required to maintain the same level of intellectual property protection."

${ }^{11}$ Veja-se, a título de exemplo, LOWENFELD, Andreas, International Economic Law, p. 108: “As intellectual property...became an increasing element in the world economy,...a new constituency for protecting intellectual property came into prominence. The high value of high technology, on the one hand, and the growing ease of reproducing or counterfeiting and "piracy'...led to an effort to bring intellectual property protection within the GATT/WTO system." 
De acordo com o que nos diz Neil Foster ${ }^{12}$, "increased IPRs in a country can directly impact on its imports in two alternative ways". De facto, em consonância com este autor, o reforço da protecção conferida aos DPI pode fomentar as trocas internacionais, na medida que encoraja os criadores a exportarem os seus produtos para o estrangeiro (se virem os seus direitos protegidos contra a pirataria), e gera a necessidade de importar esses produtos, por reduzir a capacidade de as indústrias locais levarem a cabo a imitação.

Para as potências promotoras do Acordo, como escreve Pedro Álvares ${ }^{13}$, "a falta de protecção ou um grau de protecção insuficiente da propriedade intelectual tem, necessariamente, como efeito final uma diminuição do comércio em termos globais que provoca uma menos racional afectação dos recursos e, consequentemente, uma diminuição global da riqueza, até porque os investidores ou autores de invenções se tornam progressivamente incapazes (ou pura e simplesmente não thes interessa) penetrar em mercados insuficientemente protegidos". Os países mais desenvolvidos sustentam, assim, ser o reforço dos DPI, à escala internacional, uma parte essencial do processo de liberalização.

A verdade é que os mecanismos de protecção de DPI não foram originalmente concebidos como um instrumento de promoção do comércio internacional, mas antes da actividade inventiva, pelo que há quem negue a existência de uma

12 Intellectual property rights and the margins of international trade, p. 2.

No sentido da conexão entre propriedade intelectual e comércio argumenta também Bossche, Peter Van Den, em The Law and Policy of the World Trade Organization, p. 743: "Trade and intellectual property protection are closely connected. (...) The possibility that traded products will be copied or that brand names or service marks will be used by competitors creates a strong disincentive for innovation, investment and trade."

13 O GATT (de Punta del Este a Marraquexe), p. 238. 
conexão suficientemente sólida entre a propriedade intelectual e as questões comerciais ${ }^{14}$.

Não nos demoramos em considerações, na medida em que este ponto vai sendo referenciado ao longo do texto.

\subsection{A 'justificação' do Acordo}

Basta uma leitura atenta do $1 .^{\circ}$ parágrafo do preâmbulo do Acordo ${ }^{15}$ para perceber que está aqui em causa um mecanismo de instrumentalização dos direitos de propriedade intelectual a um fim último, que é a realização do comércio internacional. Como nos diz Alberto Francisco Almeida (ob. cit., p. 36), "o motivo da consagração destas regras era assegurar um comércio mundial sem obstáculos e não regular ou proteger direitos de propriedade intelectual." E sempre será essa a ideia mais conforme à lógica de todo o enquadramento: este é um Acordo celebrado no âmbito de uma organização que, desde o início, se propôs promover a liberalização do comércio internacional; se a protecção dos DPI fosse um fim em si mesmo, ela teria continuado reservada à Organização Mundial de Propriedade Intelectual (OMPI). ${ }^{16}$

14 A título de exemplo, Yusuf, Abdulqawi, TRIPS: Backgroud, Principles and General Provisions..., p. 8: "It was therefore paradoxical that the prescription of higher standards of protection for intellectual property rights should have been advocated within the framework such an instrument as the GATT.'

15 "Desejando reduzir distorções e obstáculos ao comércio internacional e levando em consideração a necessidade de promover uma protecção eficaz e adequada dos direitos de propriedade intelectual e assegurar que as medidas e procedimentos destinados a fazê-los respeitar não se tornem, por sua vez, obstáculos ao comércio legítimo;"

16 Sobre esta diferença teleológica que deve orientar a interpretação, por um lado, do TRIPS, e, por outro, das Convenções Internacionais que continuam reservadas à administração da OMPI, ver GERVAIs, Daniel, 
Pelo menos, entendemos que tal contexto nos deve conduzir a conclusões interpretativas: o Acordo TRIPS não pode ser lido isoladamente, mas antes em conjugação com os objectivos gerais que norteiam a actividade da $\mathrm{OMC}^{17}$.

Mas, se este parece ser um pressuposto óbvio da celebração do Acordo, é de lembrar que ele se assumiu, pelo contrário, como a primeira das controvérsias, reflectida na mesa das negociações, e que não deixa de estar presente na letra do preâmbulo ${ }^{18}$.

De facto, não foi pacífica a inclusão desta matéria na agenda do Ciclo do Uruguai ${ }^{19}$ - os países em desenvolvimento sempre se mostraram fortes opositores da incorporação de standards de protecção dos DPI no contexto da $\mathrm{OMC}^{20}$. Alegavam que uma organização que nasceu para

The TRIPS Agreement - Drafting History..., p. 159: “...provisions of WIPO-administered instruments incorporated into TRIPS may be interpreted differently in the TRIPS context, where an economic, welfare-based analysis might prevail."

17 Seguimos, neste ponto, a ideia apresentada em Resource Book on TRIPS and Development, p. 13: "The protection of IPRs is part of the means to na end - to be "taken into account" within a larger strategy to promote economic growth. The core objective of the WTO is to improve worldwide standards of living."

E também Gervais, Daniel, The TRIPS Agreement - Drafting History, p. 156: "It recognises the need to read TRIPS - though it is mostly selfcontained - as part of the WTO system."

18 De acordo com Resource Book on TRIPS and Development, p. 2: "The preamble of the TRIPS Agreement reflects the contentious nature of the negotiations and the differences in perspective among the negotiating WTO Members."

19 Como bem ilustra YI-Chong, Xu, Last chance? Multilateralism, TRIPS and developing countries, p. 67: "Some see the TRIPS Agreement as the necessary condition for continuing research and development in technology while others see it as the product of patent and copyright holders trying to obtain worldwide monopolies."

${ }^{20}$ A este propósito, veja-se Trebilcock, Michael e Howse, Robert, ob. cit., p. 405: “....it was the position most developing countries that 
promover o comércio e o desenvolvimento económico não podia dedicar-se, paradoxalmente, à protecção de interesses de grupos privados (neste caso, dos proprietários de DPI). De facto, além da existência de organizações especialmente vocacionadas para a regulação desta matéria, pode ainda considerar-se que a disciplina do GATT confere, inevitavelmente, um novo enquadramento ideológico à propriedade intelectual.

"As negociações progrediram lentamente não só porque se tratava de uma matéria nova (em especial pela dimensão que se the queria imprimir), mas também porque se verificaram divergências entre os países industrializados (como os EUA, a CE ou o Japão) que desejavam um acordo muito completo e além dos objectivos inicialmente fixados, e os países em vias de desenvolvimento (como o México e o Brasil) que estavam receosos de um excesso de protecção que gerasse dificuldades no campo das transferências de tecnologia e implicasse um aumento dos custos dos produtos agrícolas e farmacêuticos (a Índia defendia que as regras do GATT só se deveriam aplicar quando se provasse distorção do comércio)" ${ }^{21}$.

Também não pode deixar de se notar a fraca representação técnica dos países em desenvolvimento ${ }^{22}$ no momento

WIPO, not GATT, was the appropriate forum for evolving stronger international rules on the protection of intellectual property rights. This position was undoubtedly influenced by the perception that developing countries have traditionally had more influence in the UN system than in the GATT."

${ }^{21}$ Almeida, Alberto Francisco Ribeiro, ob. cit., p. 39.

No mesmo sentido, veja-se também Hoekman, Bernard e Kostecki, Michel, Political Economy of the World Trading System p. 283: "The negotiation on TRIPs was one of the more difficult of the Uruguay Round, both politically and technically. The issue was relatively new to GATT and involved a North-South confrontation."

22 Falamos em "países em desenvolvimento", genericamente, mas procuramos, em rigor, abranger duas das categorias de países identificadas 
das negociações do Acordo $^{23}$, que obsta a uma desejável distribuição equitativa do poder negocial entre as partes.

A verdade é que a inclusão da matéria da propriedade intelectual nas negociações do Uruguay Round foi uma iniciativa dos EUA, seguidos depois pela União Europeia e pelo Japão.

E note-se que estes países não actuam, aqui, em representação de interesses patrióticos, mas antes movidos pela pressão de grupos empresariais privados ${ }^{24}$. Como muito bem

pela OMC: países em desenvolvimento e países de menor desenvolvimento relativo.

${ }^{23}$ Cfr., nomeadamente, MotA, Pedro Infante, O sistema GATT/ $O M C$, p. 487. Este autor aponta, como uma das razões que levou à passividade dos países em desenvolvimento no processo de negociações do Ciclo do Uruguai, a "falta de capacidade institucional e de recursos humanos para participarem efectivamente nas negociações do GATT".

Veja-se também Panagariya, Arvind, Developing Countries at Doha, p. 1230. Este autor diz-nos que, na sua esmagadora maioria, os países em desenvolvimento são demasiado pequenos e pobres para conseguirem organizar uma estratégia de negociação, o que acaba por os fazer seguir as posições definidas por entidades externas, nunca isentas.

Sobre o reduzido poder negocial dos Estados em desenvolvimento, veja-se ainda MATTHEWs, Duncan, Lessons from negotiating an amendment to the TRIPS Agreement, p. 248: "With few, if any, non-state actors opposing the TRIPS Agreement in a concerted way and developing country governments experiencing not only information deficiencies but also negotiating fatigue, pressure to avoid bilateral trade sanctions and an imperative to achieve compromise deals in a multilateral context, sustained opposition to TRIPS was not readily apparent."

${ }^{24}$ A este título, questiona Petersmann, Ernest-Ulrich, From Negative to Positive Integration in the WTO, p. 27: "If the conclusion of the TRIPS Agreement was essentially due to the powerful political and economic pressures from pharmaceutical, chemical and other industries in developed countries which own most of the industrial property rights: are there adequate safeguards that such 'producer-driven' trade policymaking processes take into account also consumer, environmental and social interests?" 
interroga Alexandre Dias Pereira 25: "Mas, não significará isto a substituição dos impostos do Estado pelas royalties das grandes empresas privadas, ficando ainda por cima o Estado onerado com os custos administrativos de fiscalização e punição das infraç̧ões?’. De facto, ao mesmo tempo que se defende a abolição de taxas aduaneiras cobradas pelos Estados, proclama-se a "justa" cobrança de rendas em benefício das grandes multinacionais proprietárias de DPI.

Os apologistas da celebração do Acordo vêm dizer que os países em desenvolvimento só têm a lucrar com a integração numa "comunidade tecnológica internacional", que os fará beneficiar das conquistas alcançadas com os processos de inovação e dinamização do comércio.

Quanto a este ponto, parece-nos essencial frisar que, para considerar legítimo este argumento, tem de ser adoptada uma perspectiva de muito longo prazo. Se, no momento em que é celebrado o Acordo, a realidade que temos é a de inúmeros países pouco desenvolvidos que se assumem como importadores de produtos que incorporam DPI, a lógica diz-nos que, para eles, a consequência mais directa do reforço da protecção destes direitos é o aumento do pagamento de royalties aos proprietários estrangeiros ${ }^{26}$. E esse aumento nos

No mesmo sentido, Dutfield, Graham e Suthersanen, Uma, Global intellectual property law, p. 33: "The insertion of 'trade-related' intellectual property rights into the Uruguay Round agenda (...) could not have been achieved without the effective lobbying activities in the USA of legal and policy activists and corporations, and a government and political establishment that, during the 1980s, was especially receptive to the diagnoses and prescriptions propounded by these individuals, firms and business associations."

25 A Revisão do Acordo ADPIC/TRIPS, p. 369.

${ }^{26}$ Cfr., por exemplo, United Nations Conference on Trade and Development, The TRIPS Agreement and Developing Countries, p. 15: “... one anticipated consequence of their adopting a stronger protection regime would be an increase in royalty payments to foreign title holders." 
custos de produção reflectir-se-á, naturalmente, num acréscimo do preço dos produtos, com prejuízo evidente sobre os consumidores (o impacto negativo acentua-se se considerarmos que estes 'consumidores' dos países menos desenvolvidos são particularmente desfavorecidos em relação a um entendimento genérico do conceito de 'consumidores', por ser significativamente baixo o seu poder de compra).

Por outro lado, terão de suportar um impacto económico negativo decorrente do acentuado decréscimo da produção nas indústrias locais (que se estruturam com base em processos de imitação) ${ }^{27}$, o que implicará uma diminuição da riqueza nacional e um aumento do desemprego, com todos os custos económicos e sociais que lhe estão associados.

As potências industrializadas assumem ainda que esta é a forma de os países em desenvolvimento garantirem e fomentarem o investimento estrangeiro ${ }^{28}$, sobretudo por os in-

27 A esta ideia se opõe, por exemplo, Carvalho, Nuno Pires, The TRIPS Regime of Patent Rights, p. 103: "it should be expected that the efficiency in the allocation of resources entailed by an adequate legal framework should compensate for the losses stemming from unemployment in the sectors involved in copying foreign, unprotected technologies. Furthermore, unemployment is not a necessary consequence of the introduction of patent protection."

28 Entre outros, Carvalho, Nuno Pires, The TRIPS Regime of Antitrust, p. 83: "In principle, if intellectual property protection is strong, right holders have more confidence in establishing partnerships in other countries..."

Ou também Maskus, Keith, Benefiting from Intellectual Property Protection, p. 369: "It is clear from empirical work that the strength of IPRs and the ability to enforce contracts have important effects on decisions by multinational firms on where to invest and whether to transfer advanced technologies through FDI."

Veja-se ainda Canotilho, J.J. Gomes e Machado, Jónatas, ob. cit., p. 48: “...embora os beneficiários imediatos desse reforço de protecção sejam os países desenvolvidos, a médio e longo prazo uma maior protecção da propriedade intelectual acabará por reverter em benefício dos Estados menos desenvolvidos. Assim é, na medida em que um forte sis- 
vestidores se sentirem protegidos contra a pirataria e a contrafacção (sendo que o investimento estrangeiro se traduziria num eficaz mecanismo de desenvolvimento). Contudo, esta sempre se apresentou como uma constatação muito dúbia ${ }^{29}$, pois não é seguro que, na prática, se verifique tal relação - há quem sustente que o investimento directo estrangeiro e a inovação nos países em desenvolvimento não dependem do nível de protecção da propriedade intelectual ${ }^{30}$. É, acima de tudo, uma conclusão apresentada pelas potências interessadas em 'vender' o Acordo aos países que se mostraram resistentes, sem que sejam seguras as premissas de que se parte.

tema de protecção de patentes e outros direitos de propriedade intelectual e industrial favorece o investimento nacional e estrangeiro, directo e indirecto, uma vez que daí resulta uma diminuição substancial dos riscos desse investimento".

${ }^{29}$ Veja-se, neste ponto, United Nations Conference on Trade And Development, The TRIPS Agreement and Developing Countries, p. 2: "While some studies, using an ad hoc and descriptive econometric approach, found no statistical relationship between membership in IPR conventions and FDI, a recent survey of potential investors from the United States of America, Japan and Germany showed that the intellectual property protection system does have detectable effects on decisions to invest in a given country."

${ }^{30}$ Neste sentido, veja-se, a título de exemplo, Trebilcock, Michael e Howse, Robert, ob. cit., p. 400: "Another line of argument is that developing countries will attract greater amounts of foreign investment and technology transfers if foreigners believe that products, processes and trade secrets will be adequately protected. Empirical evidence that this is the case is, however, sketchy and anecdotal."

No mesmo sentido, diz-nos Mota, Pedro Infante, ob. cit., p. 499, que, se a protecção dos DPI fosse efectivamente motor do investimento estrangeiro, então "muitos países em desenvolvimento teriam já adoptado anteriormente, de livre vontade, legislação que protegesse fortemente os direitos de propriedade intelectual.” Aliás, adianta este autor (p. 500) que "o facto de a China ser um dos principais países violadores dos direitos de propriedade intelectual não a tem impedido de ser um dos principais destinos do investimento directo estrangeiro". 
Mas, de qualquer forma, o argumento mais eficaz acabou por ser a situação negocial de constrangimento, que fez os países em desenvolvimento ceder neste ponto, em troca de uma maior liberalização comercial no sector da agricultura e dos têxteis ${ }^{31}$. De facto, o TRIPS foi 'imposto' aos países em vias de desenvolvimento, como contrapartida de cedências em domínios tradicionais do GATT. Refira-se que esta possibilidade não existiria no caso de o Acordo ser celebrado, como os anteriores, no contexto de negociações focadas exclusivamente no tema da propriedade intelectual. No entanto, somos levados a considerar que as vantagens que os países industrializados retiram do TRIPS são muito superiores àquelas que os países de menor desenvolvimento podem esperar de um acordo sobre a agricultura ${ }^{32}$, até porque a liberalização nos sectores tradicionais acaba por representar uma vantagem mais generalizada, enquanto que os benefícios do TRIPS só se fazem sentir em países com uma estrutura tecnológica forte.

31 Entre outros, Resource Book on TRIPS and Development, p. 4: “... the resistance of developing countries was overcome through a combination of concessions offered by developed countries in other areas (principally agriculture and textiles), and by threats of trade sanctions and, implicitly at least dismantling of the GATT."

Ver também Yusuf, Abdulqawi, TRIPS: Background, Principles and General Provisions, p. 6: "...then decided to move the negotiations to GATT where market access for the manufactured products of developing countries could be offered in exchange for their acceptance of providing better protection to IPRs."

32 Em sentido contrário ao que aqui propomos (por entender que houve um equilíbrio global entre as concessões e os beneficios por parte dos países em desenvolvimento) escreve Carvalho, Nuno Pires, The TRIPS Regime of Patent Rights, p. 104: "To this extent, it does not make sense to keep up a discussion on the advantages and disadvantages that the TRIPS Agreement brings to developing countries. An eventual balance (or imbalance) that results from TRIPS obligations implementation by developing countries should be assessed vis-à-vis concessions made by developed countries in other sectors of the WTO." 
Não pode deixar de se notar que para a celebração do Acordo foi também essencial o sistema de 'negociações em pacote' - ou se assinam todos os Acordos ou nenhum, sendo que cada um deles vincula a totalidade dos Membros da OMC. Por outro lado, na medida em que a estrutura da OMC impõe que a adesão à organização vincule cada Membro a aderir também a todos os acordos multilaterais celebrados no seu âmbito, os países menos desenvolvidos que integram este sistema não têm liberdade de escolha quanto à incorporação do TRIPS nos seus ordenamentos jurídicos (vigora o 'princípio do compromisso único').

Além de que, alegam também os promotores do TRIPS, a construção de um quadro multilateral nesta matéria acabaria por mitigar as sanções unilaterais (no sentido do acréscimo de protecção dos DPI) de que sempre seriam alvo os países menos desenvolvidos ${ }^{33}$. No entanto, note-se, quanto a este ponto, que as ameaças unilaterais permaneceram depois de celebrado o Acordo $^{34}$.

33 Neste sentido, Bossche, Peter Van Den, ob. cit., p. 743: "The initial resistance of developing countries to the inclusion of negotiations on IP protection in the Uruguay Round was overcome when they realized that they were better off with multilateral disciplines than being subject to bilateral pressure to provide IP protection."

E também Yusuf, Abdulqawi, ob. cit., p. 9: “...by threatening trade retaliation for inadequate intellectual property protection, the US, and later EEC, was able to induce significant changes in the IPR laws of many developing countries. (...) A multilateral framework came to be perceived by the developing countries themselves as a lesser evil than bilateral concessions, especially in view of the fact that it could lead to trade-offs in other areas..."

34 Cfr. Trebilcock, Michael e Howse, Robert, ob. cit., p. 434: "One issue is the continuing use by the United States of unilateral trade action...to deal with complaints about inadequate protection of intellectual property rights in developing countries, in some instances simultaneously with the pursuit of dispute settlement in the WTO." 


\section{A potencial rigidez}

\subsection{Natureza e abrangência das obrigações}

Este ponto é considerado à luz daquilo que dispõe o artigo $1 .^{\circ},{ }^{\circ} .^{\circ} 1$ e 2 do TRIPS ${ }^{35}$.

Quanto àquilo que prevê o artigo $1 .^{\circ}$, deve, em primeiro lugar, referir-se que o TRIPS impõe um patamar mínimo de protecção dos DPI, que confere aos Estados a possibilidade de promoverem uma protecção mais ampla, mas nunca mais estrita. Ou seja, o estabelecimento destes mínimos de protecção prende-se com a ideia de que existe uma estrutura base de protecção que obriga imperativamente ao Estados, sem lhes deixar qualquer margem de conformação.

Esta acaba por ser uma via subtil de permitir uma intensificação daquilo que o Acordo impõe, na medida em que se traduz numa 'porta aberta' à adopção de standards de protecção mais elevados, se não voluntariamente, pelo menos pelo menos no contexto de acordos bilaterais ou regionais posteriores ${ }^{36}$.

35 De acordo com a letra do preceito:

“1. Os Membros colocarão em vigor o disposto neste Acordo. Os Membros poderão, mas não estarão obrigados a prover, em sua legislação, protecção mais ampla que a exigida neste Acordo, desde que tal protecção não contrarie as disposições deste Acordo. Os Membros determinarão livremente a forma apropriada de implementar as disposições deste Acordo no âmbito de seus respectivos sistemas e práticas jurídicas.

2. Para os fins deste Acordo, o termo "propriedade intelectual" refere-se a todas as categorias de propriedade intelectual que são objecto das Seções 1 a 7 da Parte II."

${ }^{36}$ Veja-se, a título de exemplo, Resource Book on TRIPS and Development, p. 35: “...by setting minimum standards, but not maximum standards, TRIPS leaves an opening for bilateral and regional agreements that may significantly shift the balance of economic interests to the more powerful WTO Members, thereby further exacerbating problems in the global distribution of wealth." 
Como nos diz Daniel Gervais" 37 "...here it could be said that para.1 indirectly emphasis the fact the Agreement did not achieve all that some countries wished." No entanto, deixamos para o momento em que abordarmos a cláusula da nação mais favorecida considerações mais amplas sobre este ponto.

Cabe, por outro lado, perguntar, se estes standards mínimos serão assim tão mínimos. $\mathrm{Na}$ verdade, consideramos que o nível mínimo de protecção conferida é já bastante elevado. A este propósito, damos como exemplo o caso português, em que o Decreto-Lei n. ${ }^{\circ}$ 141/96, de 23 de Agosto, por forma a incorporar o disposto no TRIPS, vem alargar o prazo de protecção das patentes de 15 para 20 anos (por forma a incorporar aquilo que estabelece o artigo $33 .^{\circ}$ do Acordo)!

Do preceito em análise também se deduz que este é um Acordo dirigido aos Estados, que estão obrigados a incorporá-lo na sua legislação. Não se pode, no entanto, pensar que isto se traduz numa forma de atribuir maior flexibilidade à implementação das disposições aqui previstas. Isto porque há normas que, pela sua determinabilidade, têm sido consideradas directamente aplicáveis aos cidadãos ${ }^{38}$.

37 Em The TRIPS Agreement - Drafting History, p. 164

38 Esta tem sido a posição seguida por muitos tribunais, quando confrontados com casos concretos em que as normas do TRIPS não deixam margem de interpretação.

Veja-se Hase, Andres, The application and interpretation of the Agreement, p. 107: “...in many countries find it necessary to make an exegetic interpretation of the text on a case-by-case basis, in order to distinguish the scope of the obligations assumed by the states. The European Court of Justice has evaluated in each case whether the economy and the terms of the treaty provision under consideration are likely to produce direct effects on the relations between the persons for which the act is intended and third parties."

Se nos focarmos sobre o caso português, encontramos também orientações neste sentido, quer jurisprudenciais (veja-se, por exemplo, o acórdão do STJ n. ${ }^{\circ}$ 4416/04, de 14/12/2004, em que se reconhece o 
Assim, um Acordo que, numa primeira leitura, se destina a 'passar o filtro interpretativo das autoridades nacionais' (o que conduziria a um equilíbrio mais eficaz dos interesses concretamente em jogo, no contexto específico de cada país) acaba por permitir que as suas normas produzam um 'efeito directo' junto dos indivíduos, na medida em que se essa possibilidade não é negada pela letra deste artigo $1 .^{\circ},{ }^{\circ} .^{\circ} 1$, parte final ${ }^{39}$. Longe de ser pacífico, este ponto acaba por dar origem a uma diversidade de soluções entre os vários Estados.

Aliás, esta aparente flexibilidade no tocante à implementação do Acordo parece pouco conciliável com a exaustiva regulamentação da matéria, que vem anular mitigar a soberania que os Estados tinham na adopção dos padrões que consideravam mais adequados ${ }^{40}$.

efeito directo do artigo 33..$^{\circ}$ do TRIPS - disponível em http://www. dgsi.pt/jstj.nsf/954f0ce6ad9dd8b980256b5f003fa814/cb08775247c886 2c802570c700596752?OpenDocument), quer doutrinais (neste sentido argumenta, nomeadamente, Marques, J. P. Remédio, A patenteabilidade de substâncias químicas)

39 Neste sentido, veja-se, nomeadamente, Resource Book on TRIPS and Development, p. 26: “...each Member is free to determine whether it will apply the Agreement directly, and that this will depend on its legal system and practice."

Há, no entanto, autores que se mostram mais reticentes em assumir amplamente esta solução. A título de exemplo, Gervais, Daniel, The TRIPS Agreement - Drafting History, p. 164 e 165: "Because of this provision, TRIPS may be viewed as not self-executing. (...) Certain provisions of TRIPS may be considered directly applicable by a national court, but that would not be the case for the entire Agreement."

${ }^{40}$ Assim se escreve em Resource Book on TRIPS and Development, p. 21: “...the TRIPS Agreement that was concluded allows substantial flexibility in the specific implementation of IPR rules, while broadly demanding subject matter coverage for traditionally sensitive areas. The result is thus a mixed one: flexibility as to the finer aspects of implementation, yet starting from a broad scope of coverage." 
Por outro lado, não pode deixar de se notar que é com o TRIPS que, pela primeira vez, se promove uma integração positiva no âmbito da $\mathrm{OMC}^{41}$. Até então, sempre se tinha seguido a ideia de abolição de barreiras comerciais entre os Estados; com este acordo, o que se pretende é uma harmonização da legislação dos países membros. É legítimo que se ponha a questão de saber se não se estará a ir longe demais, no âmbito das atribuições da OMC.

No que toca às categorias de propriedade intelectual abrangidas (remissão consagrada no $n .^{\circ} 2$ do artigo $1 .^{\circ}$ ), mais um ponto relevante há a salientar: nem todos os DPI são abrangidos pelo Acordo, sendo que as exclusões se dão em desfavor dos países em desenvolvimento. De facto, o texto do Acordo não parte de uma definição de propriedade intelectual, optando-se antes pela técnica da enumeração exaustiva, que indirectamente exclui certas matérias.

Embora se reconheça a amplitude do TRIPS, o certo é que ele não se aplica a matérias como o conhecimento tradicional e os recursos genéticos, cuja protecção tem vindo a ser uma reivindicação por parte dos países em desenvolvimento $^{42}$. Ou seja, o Acordo cobre todos os domínios da propriedade intelectual em que os países desenvolvidos dominam claramente, e subordina à sua protecção os países que nela não têm interesse. Mas, ao mesmo tempo, também deixa

41 Cfr., por exemplo, Hoekman, Bernard e Kostecki, Michel, The Political Economy of the World Trade System, p. 274: The agreement is unique in the WTO context in that it imposes obligations upon governments to adopt a set of substantive rules in an area that traditionally has been regarded to be in the purview of domestic regulation."

${ }^{42}$ Cfr. Resource Book on TRIPS and Development, p. 38: "A number of proposals have been made to expand the subject matter scope of TRIPS, most of them coming from developing countries. These proposals would include the fields of traditional knowledge, folklore and genetic resources within the scope of TRIPS Agreement coverage." 
de parte áreas emergentes em que os países em desenvolvimento são particularmente fortes.

Muito se tem discutido em torno desta problemática. Os opositores à incorporação destas potenciais fontes de direitos no âmbito da protecção internacional da propriedade intelectual vêm dizer que lhes falta o valor económico acrescentado, na medida em que não existe uma actividade de criação/inovação; esta ideia pode contestar-se pela existência de um valor intrínseco, decorrente da sua utilidade para a humanidade.

Por outro lado, existe o interesse dos países em desenvolvimento $^{43}$ em proteger a biodiversidade no contexto dos $\mathrm{DPI}^{44}$ (que está maioritariamente localizada nos seus territórios ${ }^{45}$ ), por entenderem ser os legítimos beneficiários dos

${ }^{43}$ No sentido de que estas matérias devem ser legalmente reconhecidas, por forma a darem origem a DPI, veja-se, GIBSON, Johanna, Knowlegde and other values, p. 317: "Through the imposition of intellectual property frameworks upon traditional knowledge development, the protection of traditional of traditional knowledge as the responsibility of the community, to be managed according to customary law, is displaced as the global risk of natural and cultural resources, and the means by which the value of trade may come to be realized."

${ }^{44}$ A este propósito cfr. Trebilcock, Michael e Howse, Robert, ob. cit., p. 436: "The TRIPS Council has already received a proposal by a group of developing countries...that TRIPs be amended to address the existing lack of provisions 'to prevent biopiracy (illegal access and use) or ensure prior informed consent and fair and equitable sharing of benefits. To this end, the group proposed several conditions to acquiring patent rights related to biological materials or traditional knowledge..."

45 Cfr. Subramanian, Arvind, Proprietary Protection of the Genetic Resources, p. 382: "the basic physical reality confers an advantage on developing countries. These countries, it is estimated, are home to about 90 percent of the world's genetic resources and traditional knowledge. More than 90 percent of the world's research and development activity, however, takes place in the industrial countries." 
recursos de que dispõem ${ }^{46}$. Pretendem, dessa forma, evitar a 'biopirataria'47, que consiste na apropriação indevida dos recursos genéticos ou do conhecimento tradicional a eles associado (há registos de patentes concedidas a produtos com os seus recursos genéticos), por parte de grandes multinacionais.

Relativamente aos desenvolvimentos pós-TRIPS nesta matéria, refira-se que, em 2001, a Declaração Ministerial de Doha criou um mandato específico para examinar a discussão da relação entre o TRIPS e a Convenção sobre a diversidade biológica ${ }^{48}$. Esta previsão nasce das propostas dos países em desenvolvimento, que sentem a necessidade de compatibilizar estes 2 Acordos. Porém, a discussão tem-se prolongado, muito por causa da forte oposição evidenciada pelos EUA, sem que existam ainda soluções concretas.

E também não podemos deixar de criticar, ainda quanto a este ponto, a pouca clareza de muitas disposições do TRIPS 49 - como bem ilustra Jerome ReICHMAN" ${ }^{50}$, "my own assessment is that the TRIPs Agreement left the intelectual property glass either half full or half empty, depending on one's point of view". Isto porque se deixam numa situação de maior

46 Neste sentido se conclui em Resource Book on TRIPS and Development, p. 59: "If these kinds of interests are to be covered by TRIPS, it may be necessary to expand the categories of intellectual property, or at least expand the subject matter addressed by the existing categories."

${ }^{47}$ Veja-se Subramanian, Arvind, ob. cit., p. 383: "The term "biopiracy" began to acquire resonance. In some instances the practice led to the development of a patented product, fueling the perception that developing countries were doubly disadvantaged: not only were their resources being used without remuneration, but the resulting end product came with a higher price tag attached because of the ensuing monopoly."

48 Cfr. Panagariya, Arvind, Developing Countries at Doha, p. 1215.

49 Como nos diz Watal, Jayashree, Implementing the TRIPS Agreement, p. 363: "...the text of the TRIPS agreement is dotted with "may" provisions that are clearly optional."

50 The TRIPs Agreement Comes of Age, p. 124. 
incerteza os países que aceitaram vincular-se ao Acordo, na medida em que é ampla a margem de liberdade deixada ao critério dos Estados para a sua efectiva concretização, mas sempre no sentido de acentuar a protecção dos DPI ou, melhor dizendo, de superar os 'standards mínimos'.

\subsection{Cláusulas de não discriminação}

Quando falamos em cláusulas de não discriminação referimo-nos, de forma integrada, aos princípios contidos nos $\operatorname{artigos~} 3 .^{\circ}$ e $4 .^{\circ}$ do Acordo $^{51}$. Estas disposições consagram, respectivamente, os princípios do tratamento nacional e da nação mais favorecida.

São corolários lógicos do paradigma da liberalização do comércio internacional em condições de igualdade (formal) entre os vários países. Porém, as cláusulas de não discriminação que, no âmbito da OMC, eram tradicionalmente dirigidas a produtos ou coisas tangíveis, passam a destinar-se, com o TRIPS, a pessoas (aos proprietários dos DPI). Acabam por se traduzir numa via de prosseguir a harmonização mínima de legislações, que se pretende com este Acordo, na medida

51 De acordo com o texto do TRIPS:

"Artigo 3 Tratamento Nacional 1. Cada Membro concederá aos nacionais dos demais Membros tratamento não menos favorável que o outorgado a seus próprios nacionais com relação à proteção3 da propriedade intelectual, salvo as exceções já previstas, respectivamente, na Convenção de Paris (1967), na Convenção de Berna (1971), na Convenção de Roma e no Tratado sobre Propriedade Intelectual em Matéria de Circuitos Integrados. (...)

Artigo 4 Tratamento de Nação Mais Favorecida Com relação à proteção da propriedade intelectual, toda vantagem, favorecimento, privilégio ou imunidade que um Membro conceda aos nacionais de qualquer outro país será outorgada imediata e incondicionalmente aos nacionais de todos os demais Membros. (...)" 
em que contribuem para a progressiva construção de regras comuns entre os vários ordenamentos jurídicos.

Quanto ao princípio do tratamento nacional, ele não constitui uma novidade, nem no âmbito da OMC, nem no âmbito das Convenções sobre propriedade intelectual (era já um princípio norteador das Convenções de Berna e de Paris, no final do séc. XIX), pelo que não nos demoramos numa análise detalhada das suas implicações. Importa, contudo, salientar, que no contexto de um acordo internacional que impõe um padrão mínimo de protecção, pouca margem há para conceder aos nacionais um tratamento mais benéfico ${ }^{52}$.

Já o princípio da nação mais favorecida, que não era admitido em nenhuma Convenção anterior administrada pela OMPI e estava previsto exclusivamente para ser aplicado a mercadorias, traduz-se numa novidade do TRIPS ${ }^{53}$, e tem particular interesse ao nível da relação com os acordos de integração bilateral ou regional (sobretudo, quando uma vantagem é concedida unilateralmente e não é sujeita à cláusula do tratamento nacional).

Articulada com a ideia, acima referida, de que o TRIPS impõe standards mínimos de protecção, e deixa aos Estados a liberdade de adoptarem padrões de protecção mais elevados, esta cláusula vem permitir que os acordos bilaterais de

52 Neste sentido, Almeida, Alberto Francisco Ribeiro, ob. cit., p. 56: “Na verdade, o acordo TRIP's ao exigir (art. 1. ${ }^{\circ}$, n. $\left.{ }^{\circ} 1\right)$ um nível mínimo de tutela (quer no plano substancial quer no domínio processual) a implementar nos ordenamentos jurídicos nacionais (limitando a liberdade regulamentadora dos Membros), o princípio do tratamento nacional tem pouco de "nacional" pois o regime jurídico dos direitos de propriedade intelectual será, em grande parte, imposto pelo regime internacional consagrado no acordo TRIP's."

53 Como nos diz Yusuf, Abdulqawi, ob. cit., p. 18, "its inclusion in the TRIPS Agreement may therefore be attributed to the integration, through the Uruguay Round, of the protection of IPRs into the legal framework for international trade." 
reforço dos DPI se generalizem aos vários Estados. Ou seja, se um Estado conceder, por meio de acordo bilateral, um tratamento preferencial a outro Estado (que não seja considerado no âmbito do princípio do tratamento nacional), essas condições mais benéficas estendem-se automaticamente aos indivíduos e às empresas de todos os Estados membros do TRIPS ${ }^{54}$.

Desta forma, a maior protecção dos DPI que um Estado aceite conceder a outro (porque o TRIPS, nos termos do artigo $1 .^{\circ}$, n. ${ }^{\circ} 1$, confere apenas liberdade no sentido de aumentar os standards estabelecidos, e já não de os diminuir) logo se generaliza a todos, levando assim a um acréscimo do nível de tutela dos direitos.

Falamos, a este propósito, naquilo que ficou conhecido como cláusulas TRIPS-plus ${ }^{55}$. De facto, muitos países em desenvolvimento foram sendo encorajados, pelas grandes potências, a adoptar standards de protecção da propriedade intelectual mais elevados do que os previstos no Acordo, por via de acordos bilaterais. Assim, num momento pós-TRIPS, o regime dos DPI é reforçado no contexto de Acordos de Livre Comércio.

Tomando por base um levantamento estatístico feito por Michael Trebilcock e Robert Howse (ob. cit., p. 437), constatamos, sem admiração, que as obrigações TRIPS-plus inseridas em acordos bilaterais e regionais partem todas de propostas de grandes potências (quase na totalidade, da

${ }^{54}$ Cfr., nomeadamente, AlmeidA, Alberto Francisco Ribeiro, ob. cit., p. 61.

${ }^{55}$ Veja-se, a título de exemplo, NGUyen, Tu Thanh, Competition Law, Technology Transfer, p. 251: “...developed countries may force developing countries to accept TRIPS-plus standards (...) There are cases where developing countries formally renounce their use of the TRIPS flexibilities as a condition for obtaining further trade advantages through bilateral agreements." 
União Europeia e dos EUA) direccionadas aos países pobres do Sul, e integram, na sua esmagadora maioria, acordos com teor comercial, e não exclusivamente ligados aos DPI.

É legítimo que se pergunte se, à luz do princípio da nação mais favorecida, estão estes países obrigados a garantir esses níveis superiores de protecção aos países membros da OMC que não sejam parte no acordo bilateral. A resposta parece ser afirmativa ${ }^{56}$, salvaguardando-se apenas o caso dos acordos celebrados num momento anterior ao TRIPS, notificados ao Conselho do TRIPS e sem teor discriminatório (artigo 4. ${ }^{\circ}$, alínea d) ).

No âmbito das negociações bilaterais ou regionais que incorporem disposições TRIPS-plus, deve perguntar-se até que ponto pode um Membro ser obrigado a adoptar padrões de protecção mais extensos, em resultado da pressão negocial exercida por outro membro ${ }^{57}$. Isto porque o TRIPS, como se disse no início, assenta sobre um quadro de negociação multilateral, que deveria obstar a este tipo de obrigações impostas unilateralmente.

Os países de menor desenvolvimento, conscientes do impacto negativo a que ficam sujeitos pela operacionalidade das cláusulas TRIPS-plus (e dos constrangimentos que sofrem no sentido da sua adopção), são fortes opositores da sua

56 Neste sentido, Resource Book on TRIPS and Development, p. 88: "Since there is no exception for differential IPR treatment within arrangements negotiated after TRIPS, this may appear to be the case."

Veja-se, também, Carvalho, Nuno Pires, The TRIPS Regime of Patent Rights, p. 112: “'TRIPS plus' concessions made bilaterally under FTAs are likewise subject to the MFN when they do not apply to the nationals of the Member that makes them. (...) The fact that bilateral 'TRIPS plus' concessions extend immediately and unconditionally to all WTO Members..."

57 Cfr. Resource Book on TRIPS and Development, p. 25: "At what point would the pressured Member be relinquishing its sovereign capacity to freely bargain?" 
permissibilidade ${ }^{58}$. No entanto, há quem as veja legítimas, na medida em que emanam da 'suposta' liberdade de cada Estado, de se vincular ou não ${ }^{59}$.

A verdade é que esta ideia de igualdade teórica entre nações e indivíduos ${ }^{60}$ acaba por se reconduzir, na prática, a uma situação de desigualdade relativa dos países de menor desenvolvimento, que ficam a perder com o facto de as suas empresas se verem incapazes de competir com a estrutura e eficiência dos operadores estrangeiros. De facto, se a capacidade empresarial é, à partida, tremendamente desigual, um tratamento igualitário só vai fomentar a permanência dessas desigualdades ${ }^{61}$.

${ }^{58}$ A este propósito, veja-se Resource Book on TRIPS and Development, p. 35: "With hindsight, developing Members might have insisted more strongly that TRIPS reflect not only the minimum standards of IPR protection, but also that any increase in those standards be negotiated only within the multilateral framework of the WTO (where developing Members have a higher degree of control over outcomes)."

59 Neste sentido, Carvalho, Nuno Pires, The TRIPS Regime of Patent Rights, p. 110: “...other than in a multilateral setting, WTO Members shall not be obliged to comply with with more extensive protection than that accorded by the TRIPS Agreement. This does not mean that bilateral FTAs (or regional or plurilateral agreements) containing 'TRIPS plus' standards are necessarily TRIPS-inconsistent, provided that compliance is left to the discretion of each of the contracting parties."

${ }^{60}$ E é com base nesta ideia que muitos autores vêem com entusiasmo a inclusão da cláusula da nação mais favorecida no Acordo. A título de exemplo, veja-se EInHOrn, Talia, The impact of the WTO Agreement on TRIPS, p. 1073: "The omission of an MFN principle from TRIPs might have tempted States to seek a competitive advantage over their trade competitors by imposing bilateral agreements on third countries providing for stronger protection for their nationals than that required under TRIPs."

${ }^{61}$ Conforme se escreve em Resource Book on TRIPS and Development, p. 89: "By agreeing to treat foreign patent holders on the same basis as local patent holders on the same basis as local patent holders, develop- 
Quanto aos desenvolvimentos mais recentes no campo das cláusulas de não discriminação, ficou implícito nas discussões da agenda Doha que a melhoria do tratamento dado aos países em desenvolvimento dentro do quadro da OMC deveria passar pela adequação da extensão das cláusulas de não discriminação ao objectivo da promoção do desenvolvimento. Uma forma de prosseguir este fim seria permitir excepções a estes princípios em favor dos países menos desenvolvidos ${ }^{62}$.

\subsection{A questão da exaustão de direitos}

O TRIPS vê com inércia a questão da exaustão dos $\mathrm{DPI}^{63}$, que é considerada uma das temáticas mais controversas deste Acordo. Consubstanciando outro ponto de tensão no contexto das negociações, talvez se tenha visto nesta abstenção de regulação da matéria a via mais pacífica para solucionar a questão, até porque ela também não é expressamente tratada nas Convenções administradas pela OMPI (foi esta a forma que se encontrou de obstar à falta de consenso que se fez sentir) ${ }^{64}$.

ing Members establish a level playing field on which teams are of rather unequal strength."

${ }^{62}$ Cfr. Resource Book on Trade and Development, p. 88 e 89.

63 Esta matéria é considerada no Artigo 6. ${ }^{\circ}$ do Acordo:

"Exaustão Para os propósitos de solução de controvérsias no marco deste Acordo, e sem prejuízo do disposto nos Artigos 3 e 4, nada neste Acordo será utilizado para tratar da questão da exaustão dos direitos de propriedade intelectual."

${ }^{64}$ Como se pode ler em Gervais, Daniel, The TRIPS Agreement Drafting History and Analysis, p. 198: "This was one of the difficult issues during the TRIPS negotiation. The compromise reached was to simply exclude the matter from dispute settlement." Diz-nos ainda este autor (p. 199): "WTO Members that supported national exhaustion during the 
De facto, e em consonância com o que resulta do art. $6^{\circ}$, não tomando partido neste ponto particular, o TRIPS deixa cair a concreta solução no âmbito da liberdade de cada Estado $^{65}$. Esta mesma ideia foi reafirmada na Declaração de Doha sobre o TRIPS e a Saúde Pública ${ }^{66}$.

Em primeiro lugar, importa definir o que se entende por "exaustão" ou "esgotamento" dos DPI no contexto internacional ${ }^{67}$.

TRIPS negotiations (including Switzerland and the United States) tried to enshrine the principle in the Agreement, while others (including Australia, Brazil, Hong Kong India and New Zealand) defended so-called "international exhaustion" or, at least, the freedom for each WTO member to decide."

${ }^{65}$ Embora haja quem veja nesta opção uma forma dissimulada de solucionar a questão ainda no âmbito do Acordo. A título de exemplo, pode referir-se EINHORN, Talia, ob. cit., p. 1082: "The wording of Article 6 does not exclude the issue of exhaustion altogether from the scope of TRIPs. The better interpretation is to view this provision as procedural, the substantive issue to be decided according to the substantive rules regarding each kind of IP right in view of its subject-matter and purpose."

Do mesmo modo, há autores que ainda encontram neste preceito um mínimo de orientações interpretativas. Veja-se Carvalho, Nuno Pires, The TRIPS Regime of Patent Rigths, p. 174: " $A$ contrario, Article 6 does not prevent WTO Members from using provisions of other WTO Agreements to bring up disputes under those same Agreements. (...) On the other hand, given that it does not infringe upon the provisions of Articles 3 and 4, that measure would not be prohibited under Article 6."

${ }^{66}$ Leia-se, a este propósito, em Resource Book on TRIPS and Development, p. 106: "If there was any doubt whether Article 6 prevents Members from adopting their own policies and rules on the subject of exhaustion of IPRs, this doubt was firmly eliminated by paragraph 5(d) of the Doha Declaration on the TRIPS Agreement and Public Health."

${ }^{67}$ Para além da exaustão internacional de DPI, que é a modalidade relevante no âmbito da análise que aqui se exige, pode ainda falar-se de exaustão no plano nacional (quando o direito exclusivo de propriedade intelectual se esgota no momento em que o produto entra em circulação dentro das fronteiras nacionais) e de exaustão no plano comunitário (a colocação no mercado de um qualquer Estado-membro da União Eu- 
$\mathrm{Na}$ falta de exaustão, o detentor do DPI continua a poder controlar a exploração e circulação dos produtos que incorporam o seu direito (impondo aos potenciais adquirentes limitações relativas à utilização dos produtos), mesmo depois de serem postos por ele (ou como seu consentimento) no mercado ${ }^{68}$. Assim, negar o princípio da exaustão de direitos significa admitir que o detentor do direito de propriedade intelectual nunca perde o controlo da exploração dos produtos em que o seu direito se materializa. E isto porque se assume a autonomia dos DPI relativamente aos produtos que os incorporam ${ }^{69}$.

Nos termos da doutrina do esgotamento, pelo contrário, "o titular de um direito de propriedade intelectual, quando coloca no mercado os seus produtos, deixa de poder controlar a respectiva circulação, no sentido de que não pode opor-se às sucessivas distribuições ou revendas nem colocar condições nessas sucessivas distribuições ou regular preços nas revendas. Efectuada a primeira colocação do produto no mercado pelo titular [ou com o seu consen-

ropeia esgota o DPI em toda a União - este princípio foi expressamente formulado pelo Tribunal de Justiça no caso Deutsche Grammophon/ Metro, processo n. ${ }^{\circ} 78 / 70$, de 8 de Junho de 1971; está também consagrado, a título de exemplo, no Código da Propriedade Industrial português, nos artigos $103 .^{\circ}$ e $259 .^{\circ}$ )

68 Cfr. Resource Book on TRIPS and development, p. 93: "Without an exhaustion doctrine, the original IPR holder would perpetually exercise control over the sale, transfer or use of a good or service embodying an IPR, and would control economic life." (p. 194) "Under a doctrine of international exhaustion, goods and services flow freely across borders after they have been first sold or placed on the market under certain conditions anywhere in the world."

${ }^{69}$ Neste sentido, Bossche, Peter Van Den, ob. cit., p. 760: "Intellectual property rights are embodied in a product (...). However, they exist independently of the products to which relate. Theoretically therefore, IP rights can 'follow' products indefinitely, even after they have been legitimately sold, allowing the IP right holder to control their resale." 
timento] esgota-se o seu direito exclusivo" ${ }^{70}$. No entanto, o titular dos DPI mantém na sua esfera poderes residuais, que não colidem com a comercialização dos produtos (a essência do direito de propriedade intelectual mantém-se sempre na sua esfera jurídica, o que lhe atribui, nomeadamente, o direito de impedir que outros explorem ilegitimamente o seu direito, por exemplo, copiando um produto patenteado) $)^{71}$.

Ou seja, o que está aqui em causa é a questão de saber "se o poder que é conferido ao titular de um DPI relativamente aos produtos protegidos, subsiste ou não mesmo após a respectiva colocação no mercado"72. Note-se, no entanto, que só se considera existir exaustão quando estejam em causa direitos válidos no âmbito de uma operação comercial legítima (quando a colocação no mercado é feita pelo próprio titular do direito ou com o seu consentimento ${ }^{73}$ ).

A exaustão diz-se internacional quando o âmbito geográfico que se tem em consideração é o mais amplo - o esgotamento do DPI produz-se em todos os países. Ou seja, a comercialização de bens que incorporem um DPI

70 Cfr. Almeida, Alberto Francisco Ribeiro, ob. cit., p. 66 e 67.

71 A este propósito veja-se, nomeadamente, Carvalho, Nuno Pires, The TRIPS Regime of Patent Rigths, p. 177: "Exhaustion consumes the exclusive rights associated with commercialisation only. The patente owner, after selling a patented product, may not oppose the sale, the offer for sale, or the stocking of the product by the buyer. However, it can oppose acts that are related to the making of the patented product or the use of the patented process in making products. Likewise, exhaustion of trademarks does not allow the parallel importer to engage in acts that may affect the quality or the reputation of the branded goods. Nor can the parallel importer remove or reaffix labels."

72 Cfr. Silva, Pedro Sousa e, Direito Comunitário e Propriedade Industrial, p. 17.

$73 \mathrm{Ou}$ seja, o produto não pode representar uma violação do direito do titular; só se considera existir exaustão quando estejam em causa direitos válidos no âmbito de uma operação comercial legítima; a colocação no mercado tem de ser lícita e os produtos colocados autênticos. 
obsta a que o seu titular se possa opor a posteriores actos sobre o produto por parte de terceiros, em qualquer mercado do mundo ${ }^{74}$. Ao invés, a ausência de um princípio de esgotamento internacional de DPI permite-lhe o controlo da circulação dos produtos, a proibição de importações paralelas (questão desenvolvida adiante), a compartimentação dos diversos mercados estaduais, a criação de zonas de exclusivo $^{75} \ldots$

Num sentido mais amplo, o que aqui está em causa, e de acordo com o que nos diz Paula Carvalho ${ }^{76}$, é a "...compatibilização dos direitos e interesses dos diversos agentes económicos que se movimentam e interagem no mercado: por um lado, o direito exclusivo atribuído ao titular da criação ou sinal e respectivo interesse de, pelo seu exercício, "controlar" o mercado e, por outro, o direito e interesse dos restantes agentes quanto à livre escolha e exercício do comércio."

A ausência de consagração de um princípio de exaustão internacional de DPI tem como efeito mais directo a possibilidade de se proibirem as importações paralelas ${ }^{77}$.

${ }^{74}$ Veja-se, a este propósito, SiLva, Pedro Sousa e, Direito Comunitário e Propriedade Industrial, p. 131:“... é no domínio do comércio internacional - em que os mercados se encontram divididos por fronteiras estaduais - que mais interessa aos operadores económicos controlar a circulação dos seus produtos, em ordem à maximização dos lucros."

75 Cfr., nomeadamente, AlmeIDA, Alberto Francisco Ribeiro, ob. cit., p. 69.

76 A Violação da Licença e o Esgotamento do Direito de Marca, p. 50.

77 As importações paralelas são realizadas fora do circuito oficial de distribuição dos produtos que incorporam DPI. Por conseguinte, a proibição das importações paralelas consubstancia-se no direito de o titular de DPI impedir um terceiro de importar, sem a sua autorização, produtos que tinham sido legitimamente postos no mercado (por si próprio ou com o seu consentimento).

Veja-se, a propósito do direito das marcas, Adiers, Cláudia Marins, Importações Paralelas e seus reflexos, p. 30: "O termo importação paralela refere-se ao fenómeno pelo qual os produtos, ostentando uma marca 
Contrariamente ao que seria mais óbvio - que as importações paralelas acabam por conduzir a uma baixa dos preços dos produtos, por via do fomento da concorrência e da promoção de preços competitivos - os partidários desta ideia vêm lembrar que só a proibição das importações paralelas permite que o proprietário dos DPI possa levar a cabo uma 'discriminação de preços' ${ }^{78}$, controlando e diversificando os preços nos vários mercados para os quais exporta (a proibição das importações paralelas permite a criação de exclusividades territoriais e o isolamento dos mercados nacio-

genuína devidamente registada, fabricados em um determinado país pelo titular da marca, seus afiliados ou licenciados, são importados sem o consentimento do titular da marca no mercado local. Assim, tais produtos irão competir directamente com aqueles comercializados pelo fabricante ou distribuidor legalmente autorizados para tal, fazendo concorrência entre a mesma marca, pois ambos são produtos genuínos, protegidos pelo direito de marca e não de produtos contrafeitos."

${ }^{78}$ Veja-se, por exemplo, Carvalho, Nuno Pires, The TRIPS Regime of Patent Rights, p. 184: "The general argument behind that debate is that, given the differences in prices of patented or branded articles on different national markets, developing countries might benefit from those differences..." Este autor enfatiza mais adiante (p. 189): "International exhaustion...is believed to be the solution for problems of high prices of patented or branded articles, particularly in the public health sector. Unfortunately, this is not so, and eventually, because of unavoidable legal constrains, it may generate more problems than solutions".

Contra a ideia de exaustão internacional de direitos são ainda apresentados outros argumentos (p. 189 a 192). Por um lado, diz-se que, perante a rigidez de um regime de exaustão, os detentores de DPI tenderão a assegurar canais de distribuição exclusivos por via de cláusulas contratuais, aumentar os preços ou reduzir o fornecimento de produtos a alguns distribuidores. Por outro lado, assume-se que a exaustão internacional pode diminuir a capacidade de os governos detectarem e sancionarem práticas de pirataria e contrafacção. Diz-se ainda que permitir as importações paralelas representa uma sanção contraproducente em desfavor do investimento directo estrangeiro. 
nais), de acordo com as variáveis económicas concretamente em causa ${ }^{79}$.

Diz-se, ainda, que esta via acaba por beneficiar os países em desenvolvimento: estes podem usufruir de preços mais baixos do que aqueles que seriam praticados no caso de o proprietário dos direitos se ver obrigado a consentir importações paralelas. No fundo, assume-se que a exaustão impede o titular dos DPI de exportar a preços mais baixos, já que a partir desse momento se esgotam os seus direitos. Porém, tal hipótese está longe de se verificar na prática. Aliás, como demonstram Michael Trebilcock e Robert Howse (ob. cit., p. 430), muitas empresas farmacêuticas preferem doar medicamentos aos países pobres ao invés de os vender a custos marginais (e assim poderem levar a cabo actos de 'caridade'), por forma a evitar que esses produtos acabem por ser reimportados por países ricos, e vendidos no mercado 'não oficial' a preços mais baixos.

Outro argumento dos opositores à doutrina da exaustão passa por assumir que a faculdade de proceder à discriminação de preços permite ao proprietário dos DPI obter um maior retorno (por via de estratégias comerciais diversificadas, consoante as especificidades do mercado em causa), o que lhe permitirá investir e inovar e, em último termo, se consubstanciará num benefício para o consumidor ${ }^{80}$. Con-

79 Neste sentido, Eihorn, Talia, ob. cit., p. 1082: "Even if the rules of patent protection were similar all over the world, it is not clear that international exhaustion would have been justified. There are many other factors whereby markets differ widely, such as the specific needs of each market, differences in the cost of living, the price of production and marketing, and State regulation affecting prices or other marketing conditions (...). Forcing a patentee to make a single choice under such extreme conditions may undermine not only the basic tenets of patent law, but also those of international trade law."

${ }^{80}$ Quanto a este ponto, Resource Book on TRIPS and Development, p. 116: “...by allowing IPR holders to segregate markets and charge 
cordamos na parte em que se reconhece a possibilidade de incremento dos lucros das empresas ${ }^{81}$ (na ausência de um princípio de exaustão), mas duvidamos da relação directa que isso possa ter com o investimento por elas realizado.

Pese embora o que para trás ficou dito, não cremos que esta posição esteja suficientemente fundamentada, na medida em que os resultados teoricamente previstos dificilmente se verificarão na prática. Aliás, pode usar-se a matéria da discriminação de preços, precisamente, para argumentar em sentido contrário, a favor do comércio paralelo - assim o faz, por exemplo, Keith Maskus (ob. cit., p. 377): "Parallel imports could play an important policing role against abusive price discrimination and collusive behavior; because the colluding firms could be foreign, the loss to consumers from the firms' behavior is not balanced by a gain in local profits". Isto porque a discriminação de preços acaba por se traduzir numa faculdade negocial concedida aos proprietários dos direitos que, movidos pela obtenção de lucro, adoptarão uma estratégia de adequação dos preços à elasticidade da procura de determinado mercado.

Consideramos, assim, que permitir as importações paralelas é a forma mais segura de fomentar o comércio $^{82}$, ao mesmo tempo que se dá a possibilidade de acesso ao merca-

different prices, producers can achieve higher rates of return on their investments in intellectual property. This will permit producers to reinvest greater amounts in the creation of new and better goods and services, which is to the benefit of consumers."

${ }^{81}$ Veja-se Dutfield, Graham e Suthersanen, Uma, ob. cit., p. 35: "International exhaustion is unpopular with many international businesses since it makes it harder for them to separate national markets and set prices at levels intended to maximize their profits in each one."

82 De acordo com PAIs, Sofia Oliveira, Proibição de importações paralelas..., p. 614: “...o importador paralelo (distribuidor independente que revende num território diferente daquele em que o produto foi inicialmente comercializado pelo fabricante) pretende obter um "lucro" com a diferença de preços do produto nos vários Estados-membros, vantagem 
do dos produtos que incorporam DPI por parte dos países em desenvolvimento ${ }^{83}$.

Mas, desde logo, a nossa discordância relativamente à ausência de um princípio de exaustão no TRIPS relaciona-se com a variedade de regimes que ela acaba por viabili$\mathrm{zar}^{84}$. Isto porque, perante a ampla liberdade concedida aos Estados, constata-se uma grande diversidade de regimes, quer entre os vários páses ${ }^{85}$, quer entre os vários direitos de propriedade intelectual.

E se este é um Acordo que visa uma integração positiva, por via do estabelecimento de padrões mínimos de protecção dos DPI entre os vários Estados ${ }^{86}$, não é compreensível que acabe por negligenciar uma questão tão importante. Até

essa que poderá repercutir no preço do produto, beneficiando o consumidor final..."

No mesmo sentido, Vicente, Dário Moura, A tutela internacional da propriedade intelectual, p. 16: "A integração dos mercados pode, além disso, exigir que se tomem em consideração num país, tendo em vista o esgotamento nele dos direitos intelectuais, factos ocorridos noutro país, como a colocação em circulação dos produtos a que se referem esses direitos."

${ }^{83}$ Segundo Correa, C. M. (apud Bossche, Peter Van Den, The Law and Policy of the World Trade Organization, p. 761): "Parallel imports increase static efficiency, that is the allocation of products at the lowest possible price. Like the availability of compulsory licenses, parallel imports provide an important device to discipline markets and to induce suppliers to commercialize their products on reasonable conditions. Parallel imports from compulsory licensees may provide in some instances (...) the only way to get access to low-priced medicines."

${ }^{84}$ Cfr., nomeadamente, WATAL, Jayashree, Implementing the TRIPS Agreement, p. 363 e 364.

${ }^{85}$ Veja-se, nomeadamente, MAskus, Keith, Benefiting from intellectual property protection, p. 377: "Exhaustion policies vary widely, even among industrial economies. (...) Few developing countries restrict parallel trade. (...) This wide divergence in policies toward parallel imports suggests that there is no clear answer to whether such imports are beneficial or harmful in welfare terms."

${ }^{86}$ Veja-se o que atrás ficou dito sobre o art. $1 .^{\circ}$, n. ${ }^{\circ} 1$. 
porque, antes de optarmos pela aceitação ou recusa da doutrina da exaustão internacional, temos de reconhecer, sob a óptica dos interesses comerciais, que o mais adequado seria impor uma uniformização de regime entre os vários Estados que aderiram ao TRIPS ${ }^{87}$.

Por outro lado, estamos em crer que esta concessão de ampla liberdade aos Estados visa proporcionar-lhes uma margem de negociação fora do quadro do multilateralismo, o que contraria a própria estrutura do Acordo ${ }^{88}$. Ou seja, permite-se que os Estados mais desenvolvidos (com 'força negocial' na ordem económica internacional) venham a impor o regime mais consonante com os seus interesses, através da celebração de acordos bilaterais (veja-se o que atrás ficou dito sobre as disposições TRIPS-plus) ${ }^{89}$, que depois se estendem a todos os países por via da aplicação das cláusulas de não discriminação.

No fundo, a relevância do artigo $6 .^{\circ}$, na sua passividade, será a de impedir que determinada opção nesta matéria seja submetida ao órgão de resolução de litígios, a não ser quando haja violação das cláusulas de não discriminação.

Consideramos que esta liberdade formal acaba por se consubstanciar, na prática, na afirmação do modelo propug-

87 A este propósito, diz-nos Olavo, Carlos, Importações paralelas, p. 1449: "Acresce que, se o esgotamento não for aplicado por todos os parceiros económicos, as empresas dos países que o aplicassem ficariam em situação claramente menos favorável do que as congéneres estrangeiras, em termos de remuneração do esforço criador ou inventivo."

${ }^{88}$ Segundo o que se prevê no preâmbulo do Acordo: "Ressaltando a importância de reduzir tensões mediante a obtenção de compromissos firmes para a solução de controvérsias sobre questões de propriedade intelectual relacionadas ao comércio, por meio de procedimentos multilaterais."

${ }^{89}$ Cfr. KUANPOTH, Jakkrit, Intellectual property protection after TRIPS, p. 85: "Since TRIPS-plus arrangements prohibit international exhaustion, parallel importing is regarded as an IP infringement and cannot be carried out without the authorization of the right-holders." 
nado por aqueles Estados que tenham efectiva capacidade de condução da política económica internacional.

Acima de tudo, não se vê como é que, no contexto de uma ideologia de 'progressiva liberalização do comércio internacional', se entrega esta matéria à discricionariedade de cada Estado, e não se opta por consagrar um princípio de esgotamento dos DPI, que encorajaria o comércio livre e a concorrência saudáve $\mathrm{l}^{90}$. Pese embora o reconhecimento de posições contrárias ${ }^{91}$, cremos que esta opção vem reforçar a

${ }^{90}$ Veja-se, a este propósito, AlmeidA, Alberto Francisco Ribeiro, ob. cit., p. 66: "A não consagração do esgotamento internacional dos direitos de propriedade intelectual e consequente controlo sobre as importações pode, de facto, constituir um obstáculo relevante ao comércio internacional quando, actualmente, grande parte dos produtos e dos serviços incorporam tais direitos."

Veja-se, também, Pereira, Alexandre Dias, ob. cit., p. 384: “Assim, a inexistência de um princípio de esgotamento internacional (...) significa que os titulares de direitos poderão controlar as importações entre os Estados, exercendo o seu exclusivo no território de cada um deles. Nesse sentido, os direitos de propriedade intelectual conferem um privilégio comercial muito significativo aos titulares de direitos, privilégio esse que se traduz numa barreira ao livre comércio."

Leia-se, ainda, Yusuf, Abdulqawi, ob. cit., p. 20: “.... an international exhaustion of rights would have been more consistent with the GATT legal framework as well as with the liberalization of international trade. (...) It is therefore to be hoped that an international exhaustion of IPRs will be incorporated in a future revision of the TRIPS Agreement, so as to bring it into full conformity with the ideals of free trade underpinning the WTO agreements."

No mesmo sentido, em Resource Book on TRIPS and Development, p. 94: "From the standpoint of those favouring open markets and competition, it may appear fundamentally inconsistent to permit intellectual property to serve as a mechanism to inhibit trade."

91 Em sentido contrário ao que aqui propugnamos veja-se, por exemplo, Carvalho, Nuno Pires, The TRIPS Regime of Patent Rigths, p. 184 e 185: "It is a common mistake to see international exhaustion as a natural element or corollary of international free trade. (...) The rationale of the TRIPS Agreement is that barriers and distortions to free trade of 
tendência de criação de monopólios territoriais, que acabarão por funcionar como barreiras à realização do comércio e impedir a operacionalidade do postulado da livre circulação de mercadorias. Além de que a integração dos mercados deveria "exigir que se tomem em consideração num país, tendo em vista o esgotamento nele dos direitos intelectuais, factos ocorridos noutro país, como a colocação em circulação dos produtos a que se referem esses direitos" 92 .

Podemos ainda apontar razões de natureza legal e económica no sentido de justificar um regime de exaustão ${ }^{93}$. Por um lado, a doutrina do esgotamento é conciliável com a função que se reconhece a estes direitos, compreendendo-se que as prerrogativas atribuídas pelo direito não vão além do objectivo para o qual foi concebido. Isto porque os DPI não são direitos absolutos, mas instrumentalizados aos fins que visam cumprir. Assim, depois de cumprirem a função à qual estão associados, não se entende que estes direitos subsistam na sua plenitude.

A verdade é que não nos parece legítimo que o titular dos direitos, depois de colocar no mercado os produtos que os incorporam, continue a poder controlar a sua circulação (o que significa opor-se à comercialização em certas zonas, a certos consumidores, a determinado preço, ou à importação sem a sua autorização) restringindo a natural liberdade dos potenciais adquirentes e obtendo receita de uma situação de monopólio mais do que uma vez. O exclusivo conferido

\footnotetext{
legitimate goods occur in the absence of intellectual property." Em resposta a esta ideia, propomos questionar a própria racionalidade do Acordo como meio de prossecução do livre comércio - são, contudo, ideias que desenvolveremos mais adiante, a título de conclusão.

92 Cfr. Vicente, Dário Moura, A Tutela Internacional da Propriedade Intelectual, p. 16.

93 Cfr. Carvalho, Nuno Pires, The TRIPS Regime of Patent Rigths, p. 177 e 178.
} 
por estes direitos não pode ser prolongado ao ponto de se permitir a criação de entraves ao regular funcionamento do mercado. E permitir as importações paralelas é assegurar a livre concorrência em condições de igualdade, na medida em que está em causa o mesmo produto.

Parece-nos até antagónico que os mais acérrimos apologistas da liberalização do comércio venham, quando se põe a questão do esgotamento internacional dos DPI, defender as virtudes da segregação de mercados e da discriminação de preços. Como muito bem se escreve em Resource Book on TRIPS and Development (p. 117): "If it is correct that price discrimination as a general proposition favours developing countries, this might imply that liberal trade rules are not the most beneficial for them."

\subsection{Cumprimento do Acordo e resolução de litígios}

Esta é uma matéria ${ }^{94}$ fundamental no que respeita à diferença marcada pelo TRIPS relativamente às Convenções anteriores sobre DPI. É pela 'força' que o sistema da OMC representa ("the protection of IP depends not only on substantive norms providing minimum standards of protection, but also on procedural rules effectively enforcing them ${ }^{\prime \prime 5}$ ) que os apologistas do proteccionismo intelectual querem ver este acordo firmado dentro desta organização de índole comercial ${ }^{96}$. De facto, a inserção desta matéria no âmbito de uma estrutura ligada ao

${ }^{94}$ Tomamos em consideração, para a análise deste ponto, o disposto nas partes III, IV eV do Acordo - artigos 41. ${ }^{\circ}$ a $64 .^{\circ}$.

95 Cfr. Bossche, Peter Van Den, ob. cit., p. 793.

96 Cfr., nomeadamente, LowENFELD, Andreas, International Economic Law, p. 108: " as the GATT system was being strengthened, the proponents of including intellectual property within that system aimed to bring the arrangements for dispute settlement and trade-related sanctions 
comércio tem como principal vantagem poder submetê-la à força executória, permitida quer por via do órgão de resolução de litígios, quer pela adopção de sanções comerciais retaliatórias. A verdade é que aqueles que procuram uma estrutura institucional forte, capaz de garantir a efectividade das disposições do Acordo, a encontram na $\mathrm{OMC}^{97}$.

Quanto ao sistema de solução de controvérsias, o artigo $64 .^{\circ}$, n. ${ }^{\circ} 1$ contempla uma submissão geral àquilo que já era previsto no quadro do GATT. No entanto, e perante a oposição dos países em desenvolvimento em alargar as sanções mesmo a casos de não violação de normas e a outras situações $^{98}$ (por entenderem que isso poderia conduzir a uma extensão da protecção conferida pelo TRIPS que extravasasse aquilo que era previsto pelas suas normas), o n. ${ }^{\circ} 2$ deste preceito concede uma moratória, que expirou a 1 de Janeiro de 2000. Nesta medida, percebe-se que foram pouco consideradas as preocupações dos países em desenvolvimento, que temiam uma estratégia de dilatação do sentido literal das disposições do TRIPS, funcionalizada aos interesses dos potenciais queixosos. Passados 5 anos, permanecem as razões que fundamentavam as suas preocupações.

Em termos estatísticos, é importante notar que as questões submetidas à apreciação do órgão de resolução de litígios são, na sua esmagadora maioria, provenientes de queixas apresentadas pelos países que foram os interessados na cele-

and retaliation to bear on member states that did not carry out the obligations to be imposed."

${ }_{97}$ Leia-se, a este propósito, Trebilcock, Michael e Howse, Robert, ob. cit., p. 415: "There is a wide range of obligations to provide other Members with access to appropriate mechanisms to enforce intellectual property rights. These provisions constitute a largely unprecedented degree of control by an international regime over domestic civil and administrative procedures."

98 Cfr. Bossche, PeterVan Den, ob. cit., p. 800 e 801. 
bração do Acordo ${ }^{99}$. Em consequência, os países de menor desenvolvimento tornam-se meros 'participantes passivos' deste sistema.

Ao contrário do que poderia esperar-se, esta estrutura não chega a atender às especificidades dos casos concretos a que o TRIPS abstractamente se aplica. Pelo contrário, está igualmente vinculada aos interesses que dominaram o texto do Acordo, traduzindo-se num mecanismo de operacionalidade das suas disposições ${ }^{100}$, por forma a assegurar o seu efectivo cumprimento. Se, teoricamente, se podia conceber que o órgão de resolução de litígios promovesse a redução das assimetrias que o texto do Acordo quis acentuar, aquilo que na prática se verifica está muito longe desta hipótese.

No entanto, não podemos deixar de referir aqueles que vêem no mecanismo de resolução de litígios uma mais-valia para os países em desenvolvimento, na medida em que constitui um reforço do sistema multilateral, por oposição aos meios de sanção unilateral, de que vinham sofrendo de forma bastante mais desfavorável ${ }^{101}$. Contudo, se olharmos

99 A este propósito, veja-se a constatação estatística apresentada por WATAL, Jayashree, ob. cit., p. 365: "Up to January 2002, WTO members had invoked the dispute settlement procedures 24 times, in 20 distinct cases. In the overwhelming majority of the complaints (16 of the 24), the United States was the complainant. The EC was the complainant in 6 cases, Canada in 1, and Brazil in 1."

${ }^{100}$ Veja-se a posição de Hase, Andres, ob. cit., p. 124: "WTO's multilateral dispute settlement mechanism should not serve the same goals that some industrialized countries pursue by means of unilateral trade actions, namely, to unreasonably narrow the freedom that TRIPS itself acknowledges to developing countries to establish the precise scope of the exclusive rights of right holders under domestic law."

101 Entre os que sustentam esta posição, veja-se GAD, Mohamed, TRIPS Dispute Settlement and Developing Country Interests, p. 332: “...it is acknowledge that DCs [developing countries] did achieve some positive gains from the dispute settlement system. The DSU aims to provide se- 
para aquilo que é a realidade prática, constatamos, como acima referimos, que os países pobres nem por isso deixaram de estar sujeitos a pressões unilaterais oriundas das grandes potências.

Neste ponto, cabe-nos também referir o papel dos Painéis e do Corpo de Apelação na interpretação das disposições do TRIPS. A importância desta função resume-se a duas razões principais ${ }^{102}$ : por um lado, mitiga-se o natural desfasamento na leitura das normas do Acordo entre os vários membros (que será previsivelmente acentuado, tendo em conta as realidades tão distintas que representam); por outro lado, concretiza-se a especial natureza do TRIPS, que não se pode equiparar às Convenções sobre a matéria que o precederam, por estar vinculado a orientações comerciais. No entanto, o mais óbvio é que a margem de liberdade permitida por algumas disposições do TRIPS seja usada favor das "forças" que o fizeram nascer.

Deve considerar-se, ainda, a possibilidade de recurso ao sistema de retaliação como mecanismo de cumprimento das disposições do TRIPS, utilizando a propriedade intelectual como 'arma de arremesso'. Mas, como nos diz Alberto Francisco Ribeiro Almeida (ob. cit., p. 76), "o sistema de retaliação funcionará muito mais a favor dos países industrializados (exportadores de produtos que incorporam direitos de propriedade intelectual) e contra os países em vias de desenvolvimento (as sanções unilaterais passaram a ser multilaterais e justificadas ao abrigo da OMC), do que vice-versa (em virtude do débil poder económico destes países)”.

curity and predictability to the multilateral trading system, most importantly through the outlawing of unilateral trade retaliation measures..."

102 Cfr. Gad, Mohamed, ob. cit., p. 353. 


\section{Potencial flexibilidade}

\subsection{Objectivos e princípios}

Optamos por uma análise conjunta dos artigos $7 .^{\circ} \mathrm{e}$ 8. ${ }^{0103}$, na medida em ambos que se apresentam como fórmulas interpretativas das disposições do Acordo, veiculando as ideias que (supostamente) presidiram à elaboração do TRIPS. Será esta, no entanto, uma via de dissimulação dos fins que efectivamente se visam alcançar?

De facto, estes preceitos, em termos de técnica legislativa, devem representar parâmetros interpretativos para todo o texto do Acordo. Deveria então assumir-se, com base numa interpretação literal destas disposições, que o seu conteúdo constitui o critério de avaliação da legitimidade de todas as normas do Acordo ${ }^{104}$. Não cremos, contudo, que isso se te-

\section{3 "Artigo 7 Objectivos}

A protecção e a aplicação de normas de protecção dos direitos de propriedade intelectual devem contribuir para a promoção da inovação tecnológica e para a transferência e difusão de tecnologia, em benefício mútuo de produtores e usuários de conhecimento tecnológico e de uma forma conducente ao bem-estar social económico e a um equilíbrio entre direitos e obrigações.

Artigo 8 Princípios

1. Os Membros, ao formular ou emendar suas leis e regulamentos, podem adoptar medidas necessárias para proteger a saúde e nutrição públicas e para promover o interesse público em sectores de importância vital para seu desenvolvimento socioeconómico e tecnológico, desde que estas medidas sejam compatíveis com o disposto neste Acordo.

2. Desde que compatíveis com o disposto neste Acordo, poderão ser necessárias medidas apropriadas para evitar o abuso dos direitos de propriedade intelectual por seus titulares ou para evitar o recurso a práticas que limitem de maneira injustificável o comércio ou que afectem adversamente a transferência internacional de tecnologia."

104 Neste sentido, Almeida, Alberto Francisco Ribeiro, ob. cit., p. 49: "Os objectivos do art. 7. (proposto pelos países em desenvolvimento) 
nha verificado no momento da redacção - é que estas regras de carácter geral contrastam com os resultados a que inevitavelmente conduzem as normas especificamente previstas para as diversas categorias de direitos de propriedade intelectual.

Assim, estes reconhecimentos, com relevo ideológico mas de natureza excessivamente vaga ${ }^{105}$, não se desprendem do plano meramente formal ${ }^{106}$. Constituirão uma forma de "compensar" o grande desfavor que implicitamente se reconhece aos países em desenvolvimento - mas essa compensação não vai além do texto do Acordo ${ }^{107}$.

podem constituir fundamento para a não protecção ou aplicação efectiva de um direito de propriedade intelectual quando não exista "promoção da inovação tecnológica" ou estímulo à "transferência e divulgação de tecnologia".

Em sentido contrário, Carvalho, Nuno Pires, The TRIPS Regime of Antitrust, p. 99, defende que estas disposições não deverão exercer impacto sobre a interpretação de outras normas: “...the concern about the anticompetitive dimension of intellectual property presided over TRIPS negotiations and was accordingly translated into language actually contained in the Agreement. Therefore, the language of Article 7 (as well as of Article 8) may not be invoked as a justification to change the rules contained in the Agreement."

${ }^{105}$ Entre outros, Carvalho, Nuno Pires, The TRIPS Regime of Antitrust, p. 78: "The language of Article 7, however, does not allow it to become na operational provision for the single reason that it is inaccurate."

${ }^{106}$ Para ilustrar a ideia de que estas disposições nos dão poucas garantias acerca da sua operacionalidade, veja-se NGUYEn, Tu Thanh, Competition Law, Technology Transfer and the TRIPS Agreement, p. 29: "Although encouraging and promoting technology transfer is one of the objectives of the TRIPS Agreement, one essential concern has been raised, and continues to be raised. It is whether international technology transfer, especially the technology transfer from developed country Members to developing country Members, actually takes place when IP protection merely provides a platform for technology transfer but does not guarantee the transfer in practice."

107 Entre outros, Yusuf, Abdulqawi, ob. cit., p. 12: "To the extent that the operative provisions of the TRIPS text principally reflected the 
Afirma-se, desde logo, uma prevalência do interesse público, a que todos os interesses privados devem, à partida, estar subordinados. O que está em causa nestas previsões é uma ideia de equilíbrio necessário, entre os interesses privados dos criadores intelectuais e o interesse público do acesso à ciência, tecnologia e cultura ${ }^{108}$ - que podemos assumir como valores que existem numa relação de potencial antagonismo $^{109}$. E é também uma ideia de limite mútuo: tanto o interesse público como o privado só podem concretizar-se dentro dos limites do outro interesse com que concorrem ${ }^{110}$.

positions of the developed countries and established higher standards of protection for IPRs, it would be appear that the developing countries found comfort and consolation in the clear statement of the objectives they proposed in the preambular clauses as well as in Article 7, together with the recognition of some of the principles they suggested in Article 8."

108 Leia-se, a este propósito, Trebilcock, Michael e Howse, Robert, ob. cit., p. 397: "The level of intellectual property protection each country decides to afford will thus be rationally related to wheter its comparative advantage resides more in innovation or imitation and adaptation of innovations made elsewhere, and the relative weight it gives to the interests of consumers (including its own producers who are consumers of inputs), imitators and innovators."

109 Por exemplo, a concessão de uma patente representa a constituição de um monopólio a favor do criador, que obtém lucros através das "rendas" cobradas aos utilizadores da sua criação, que, no âmbito internacional, são os países importadores de tecnologia. É certo que isto se consubstancia num estímulo à inovação, mas não podemos negar que também se produzem prejuízos, pelo menos no curto prazo, para o bem- estar dos consumidores, que vêem os produtos encarecidos.

Devemos considerar o direito que os criadores têm a usufruir dos frutos do seu trabalho, mas temos de assumir também que é a própria sociedade que oferece o contexto em que esse trabalho pode ser desenvolvido, e posteriormente aplicado. Além de que a quantidade de criação intelectual, contrariamente ao que se passa com os bens físicos, não diminui com o consumo.

${ }^{110}$ No entanto, há quem negue que estes interesses se limitam mutuamente, considerando antes uma prevalência geral do interesse 
Se é verdade que a protecção concedida aos proprietários de DPI lhes garante as condições necessárias à continuação da sua actividade criativa (por lhes garantir uma remuneração que permita o investimento), não é menos verdade que uma protecção excessiva pode conduzir à criação de monopólios que acabam por funcionar como uma barreira ao comércio legítimo ${ }^{111}$. Entendendo-se os DPI como direitos de exclusão de outros, a ideia de equilíbrio radica na necessidade de conter esse poder, e evitar que os proprietários de DPI exerçam os seus direitos de uma forma que extravase o objectivo legal que presidiu à sua concessão ${ }^{112}$.

privado, que pode, em algumas situações, ser limitado pelo interesse público. Neste sentido, veja-se Carvalho, Nuno Pires, The TRIPS Regime of Antitrust, p. 103: "The obligations that create the balance do not diminish rights - they simply make it impossible (or sanctionable) for the intellectual property owner to use his right to say 'no' in a manner that is not wished by the lawmaker (or, in other words, to use his right to say no in an abusive manner)."

Em sentido oposto, há quem instrumentalize a concessão dos direitos privados ao fim último que é a prossecução do interesse público. Veja-se, por exemplo, Trebilcock, Michael e Howse, Robert, ob. cit., p. 399: "Extending protection from 15 to 20 years will only makes sense if the welfare gain from the added incentive to innovation outweights the welfare loss from deterring competition with respect imitations of the technology."

${ }^{111}$ Ver, nomeadamente, GervaIs, Daniel, The TRIPS Agreement Drafting History, p. 204: "If, on the other hand, too much protection is given, the resulting monopoly over a given field of activity or industry may eventually stifle necessary competition and innovation. This impact is especially noticeable in cases where intellectual property rights are used to stop a type of (unauthorized) use which would be conducive to greater public welfare or act as a stimulus to further creativity and innovation but which is otherwise of limited commercial significance."

112 Temos, no entanto, quem se oponha à ideia de que este artigo 7. ${ }^{\circ}$ pode servir como mecanismo de contenção dos DPI conferidos aos seus legítimos proprietários. A este propósito, escreve CarvalHo, Nuno Pires, The TRIPS Regime of Patent Rights, p. 219: "The reference in the 
No entanto, e como já deixámos antever, esta ideia de necessária ponderação de interesses parece-nos viciada pela sobrevalorização de alguns deles.

Outra ideia central, que nos deve condicionar todo o discurso, é a de que os potenciais efeitos do Acordo não podem ser avaliados de modo uniforme, mas estarão, de alguma forma, indexados ao nível de desenvolvimento de cada país e às especificidades de cada sector produtivo ${ }^{113}$. Assim, o concreto equilíbrio só poderá ser alcançado se considerarmos o particular contexto económico de cada país, e a diferente sensibilidade que nos exige cada uma das diferentes áreas em que são aplicados os $\mathrm{DPI}^{114}$ (por exemplo, não podemos

TRIPS Agreement to the need for a balance of rights and obligations has been seen by many as a permit to seek the diminution of rights. However, that is not true. The measures that can result in the diminution of rights of intellectual property holders are specifically addressed in the TRIPS Agreement (...) Article 7 cannot be used as a mechanism to go beyond those limitations; otherwise, their identification in other provisions of the Agreement would be redundant."

Contrariamente, em consonância com o que aqui propugnamos, temos, por exemplo, Hase, Andres. Veja-se o que escreve em ob. cit., p. 118: "It also in the light of the objectives set forth in Article 7 and 8 of TRIPS that exceptions that members may establish in their national IPRs regimes to the exclusive rights of the owners of copyright, trademarks, industrial designs and patents should be considered." E avança com a ideia de que a liberdade de introduzir excepções e limitações aos DPI é a única forma de atenuar os custos sociais suportados pelos países em desenvolvimento com este Acordo (p. 120).

${ }_{113}$ Neste sentido, Resource Book on TRIPS and Development, p. 15: "...there are sound reasons to conclude that the role of IPRs will be different in the economies of industrialized, developing and least-developing countries. (...) There are those who would advocate a nuanced approach that would take into account the industry-specific..."

${ }^{114}$ Consideramos defensável a adopção de diferentes níveis de protecção para as diferentes indústrias, consoante os desafios e os interesses que o binómio inovação vs. imitação representa no caso concreto. 
considerar da mesma forma a protecção de DPI no âmbito da indústria automóvel e da indústria farmacêutica!)

Não concordamos com aqueles que vêem o fortalecimento destes direitos, genericamente, como gerador de efeitos positivos na criação de condições para o desenvolvimento económico. Neste sentido temos, por exemplo, Nuno Pires Carvalho ${ }^{115}$, a defender que o reforço dos DPI promove a efectiva transferência internacional de tecnologia, na medida em que assegura a confiança dos proprietários dos direitos no funcionamento do mercado e reduz os custos que eles teriam para fazer funcionar os meios privados de protecção dos seus direitos.

É que não podem deixar de se considerar os potenciais efeitos deste regime sobre a concorrência ${ }^{116}$, evidenciando-se a ideia, negligenciada pelo TRIPS, de que uma protecção excessiva dos DPI também pode provocar distorções no comércio, fazendo com que o 'monopólio temporário' concedido aos titulares dos direitos tenda a eternizar-se, com pre-

115 The TRIPS Regime of Antitrust, p. 83. E conclui ainda este autor (p. 86): "Any initiative to increase flows of technology that involves the diminution of intellectual property standards...in developing countries is condemned to fail."

116 Veja-se United Nations Conference on Trade and DevelopMENT, The TRIPS Agreement and Developing Countries, p. 3: "Without the balance of interests that intellectual property systems intend to provide between information creators and users, there is a risk of insufficient investment in technological innovation. If, however, the regulatory balance tips too far in favour of innovators at the expense of competitors, intellectual property rights may tend to misallocate the scarce resources devoted to research and development $(\mathrm{R} \& \mathrm{D})$ and reduce the efficiencies that flow from reverse engineering and from cumulative, sequential innovation generally. Moreover, the legal barriers to entry that result from overly protectionist measures may gradually weaken the overall competitiveness of national innovation systems with respect to other systems that allow entrepreneurs to operate in less protectionist environments." 
juízo para os potenciais concorrentes e, em última instância, para os consumidores.

Nascida das propostas apresentadas pelos países em desenvolvimento ${ }^{117}$, esta consagração, no artigo $7 .^{\circ}$, dos objectivos do TRIPS, mostra-se consonante com os fins que genericamente devem orientar a actividade da OMC: o bem-estar económico e social. No entanto, note-se que, constituindo à partida uma disposição de carácter geral, este artigo $7 .^{\circ}$ incide apenas sobre os DPI que foquem a inovação em produtos ou serviços (estarão sobretudo em causa as patentes), e não já aqueles que visem apenas fins de distintividade comercial (como as marcas ou as indicações geográficas). Neste seguimento, conclui Nuno Pires Carvalho ${ }^{118}$ : "Article 7 states the objectives of a few areas of intellectual property rights only."

Por outro lado, não é seguro que o reforço dos DPI seja o caminho para alcançar um maior nível de inovação e, consequentemente, promover o bem-estar económico-social. Trata-se mais de uma construção teórica, ao serviço daqueles que querem apregoar os potenciais benefícios do Acordo, do que de uma evidência empírica ${ }^{119}$.

117 Cfr. Gervais, Daniel, The TRIPS Agreement - Drafting History, p. 203: "This provision, unchanged since the 1990 Brussels Ministerial Meeting, follows from provisions in the proposal tabled by a group of developing countries."

Veja-se também Yusuf, Abdulqawi, ob. cit., p. 10: “The inclusion of provisions on objectives and principles in the TRIPS Agreement was prompted by the developing countries' insistence on the link between the protection of IPRs and the promotion of social and economic and technological development."

118 Em The TRIPS Regime of Antitrust, p. 79.

${ }^{119}$ Veja-se, entre outros, WatAL, Jayashree, ob. cit., p. 364 e 365: "There is a substantial and growing body of literature on the economic impact of stronger IPR protection in developing countries, as measured through empirical studies. Unfortunately, few studies have yielded clear-cut 
Não podemos ainda deixar de dizer que, no caso de estes serem os verdadeiros fins do Acordo, ele se teria revelado uma tentativa frustrada ${ }^{120}$.

Quanto ao artigo 8. ${ }^{\circ}$, que aparentemente se destina a proteger o interesse público e as economias mais débeis, não podemos deixar de notar que, ao impor uma exigência de compatibilidade dos meios utilizados com as disposições do Acordo (parte final do n. ${ }^{\circ} 1$ ), acaba por restringir, em muito, as medidas que, à primeira vista, parece autorizar.

E não nos parece que esta disposição se consubstancie em verdadeiros princípios do Acordo, mas talvez mais na consideração de eventuais 'medidas de excepção' à orientação seguida pelo TRIPS, na generalidade das suas normas - ou talvez uma concessão geral, para obstar à rigidez que implicitamente se reconhece no texto do Acordo ${ }^{121}$. Até porque uma ilação directa se pode retirar da letra do preceito: se se prevêem mecanismos de contenção é porque se admite a que a protecção concedida pelo Acordo é, pelo menos potencialmente, excessiva.

Pese embora o tendencial carácter de mera aparência, não deixe de se notar o maior sentido conferido a estes pre-

results. (...) there has been no empirical evidence on the relationship between stronger IPRs and the level of domestic creativity and innovation in developing countries."

${ }^{120}$ Cfr. NGuyen, Tu Thanh, ob. cit., p. 277: “...developing countries, while negotiating and signing the TRIPS Agreement, hoped that global IP protection would increase technology transfer from developed to developing countries. However, statistics indicate that the asymmetry in technological capacities between developed and developing countries did not decrease, but even tended to increase."

121 Assim o diz Carvalho, Nuno Pires, The TRIPS Regime of Antitrust, p. 105: “Although named 'Principles', Article 8 does not contain any legal principle, but a mere clarification of how concessions made as a result of negotiations on TRIPS may affect the freedom of WTO Members to handle matters of public policy." 
ceitos com a Declaração de Doha ${ }^{122}$ sobre o TRIPS e a saúde pública, que reflecte a conexão existente entre o direito das patentes e o acesso a medicamentos para combater problemas graves de saúde pública. Muito por causa da pressão exercida por Organizações Não Governamentais (doravante, ONG's), já que esta questão se liga a pontos muito sensíveis, que apelam à intervenção de estruturas não comerciais, assumiu-se que a protecção da propriedade intelectual não deveria passar ao lado de causas públicas como o combate a doenças com taxas de incidência catastróficas. Neste sentido, é possível encarar estas disposições como uma 'estrutura de legitimação’ da aplicação de mecanismos de flexibilização do Acordo (como as licenças compulsórias ou os regimes de transição). Há, no entanto, quem negue esta ideia, argumentando que diminuir a protecção do direito da patente é desincentivar o investimento e a investigação em medicamentos, o que afectará, globalmente, toda a população ${ }^{123}$.

122 Cfr. Gervais, Daniel, The TRIPS Agreement - Drafting History, p. 211: "The impact of the Doha Declaration could convince a panel to take a longer look at how these provisions should be interpreted in the context of the Agreement as a whole."

123 Partidário desta ideia, diz-nos Carvalho, Nuno Pires, The TRIPS Regime of Patent Rights, p. 234: "Poor countries have serious problems of access to pharmaceutical products (and all other essential products, for that matter), because they cannot afford to buy them; but all countries (both rich and poor) have a still more serious problem, which is the lack of access to drugs that do not exist yet (...). Some misguided commentators and developing-country negotiators may understand that patents create obstacles against accesse to existing products. (...) However, they forget that, without patents, no country will accede to nonexisting products." 


\subsection{Regimes de transição}

O que aqui está em causa é o alargamento de prazos ${ }^{124}$ para efectiva incorporação do Acordo, sendo que há quem veja esta previsão como a maior das flexibilidades concedidas aos países em desenvolvimento no contexto do TRIPS ${ }^{125}$.

Não podemos assumir, contudo, que este seja um mecanismo de obstar à rigidez do Acordo, mas antes uma inevitabilidade (perante a falta de meios dos países em desenvolvimento), tendo em conta o grande desfasamento que, ao nível da protecção da propriedade intelectual, existia entre aquilo que foi plasmado no Acordo e os regimes jurídicos, à época, vigentes em alguns Estados ${ }^{126}$.

De facto, um contexto de desenvolvimento em que fosse viável a aplicação destes níveis de protecção não se constrói em 10 anos. É que a protecção da propriedade intelectual não tem um valor autónomo, mas só pode emergir

${ }^{124}$ São aqui considerados os artigos $65 .^{\circ}$ e $66 .^{\circ}$ do Acordo, que prevêem um alargamento dos prazos para efectiva incorporação do Acordo, quando em causa estejam países com reduzidos graus de desenvolvimento.

${ }^{125}$ Nesse sentido, Gervais, Daniel, Intellectual Property, Trade and Development, p. 26.

${ }^{126}$ No mesmo sentido ao que aqui propugnamos, Leme, Letícia Frazão Alexandre de Moraes, O tratamento especial e diferenciado dos países em desenvolvimento, p. 138: "O estabelecimento de períodos de transição reflecte as dificuldades de adaptação a alguns acordos. (...) Supunha-se que, nesse período, seria possível construir a capacidade humana e institucional necessárias para editar a legislação adequada e implementar efectivamente o acordo... sem a obrigação de fornecer "aid for trade", longos períodos de transição pouco significam diante da magnitude da tarefa a ser empreendida. Além disso, alguns analistas questionam em que medida os países em desenvolvimento deveriam destinar recursos escassos para implementação de acordos que lhes darão pouco ou nenhum retorno." 
como factor de desenvolvimento se integrada num ambiente propício $^{127}$.

Importa lembrar que o reforço dos DPI terá de constituir uma evolução natural, indexada ao nível de desenvolvimento de um país, e não deve passar por uma imposição 'forçada' sem condições reais para produzir efeitos benéficos. O que se passa, ao contrário do que nos parece desejável, é que o 'mundo desenvolvido' quer impor, ao 'mundo em desenvolvimento', standards de protecção para os quais este ainda não está preparado.

A verdade é que os países que são hoje desenvolvidos estiveram também, no passado, num grau de desenvolvimento em que lhes interessava desconsiderar estes direitos ${ }^{128}$ - a história mostra-nos que os países ricos prosperaram, em muito, devido a mecanismos de imitação que precederam uma sólida estratégia de inovação. Somos apologistas da ideia de que os processos de imitação serão parte do processo normal de conhecimento.

Todavia, esta é uma disposição em que se tem sentido particularmente o efeito dos desenvolvimentos posteriores

127 Neste sentido, Carvalho, Nuno Pires, The TRIPS Regime of Antitrust, p. 82: "But if the country does not have the legal and social infrastructures that are of the essence for individual entrepreneurship to thrive, such as social and political stability, a reliable court system, and a free market environment, the impact of raising the standards of intellectual property will be extremely thin."

128 Neste sentido, Yusuf, Abdulqawi, ob. cit., p. 4: "When the United States was still a relatively young and developing country, for example, it refused to respect international intellectual property rights on the grounds that it was freely entitled to foreign works to further its social and economic development."

Veja-se também Dutfield, Graham e Suthersanen, Uma, ob. cit., p. 8: "The historical record strongly suggests that many of today's economic leader countries were themselves 'knowledge pirates' in the past, and benefited from being so." 
ao momento da celebração do Acordo ${ }^{129}$. Todos eles no sentido de alargar ainda mais os períodos de transição, adiando a integral entrada em vigor do TRIPS. Assim, a Declaração de Doha para o TRIPS e a Saúde Pública (parágrafo 7) vem assumir que, no âmbito dos produtos farmacêuticos, os países menos desenvolvidos podem diferir a efectiva incorporação do Acordo até 1 de Janeiro de 2016. No mesmo sentido, o Conselho do TRIPS, para além de dar exequibilidade a esta orientação emitida pela Declaração de Doha, vem, em 29 de Novembro de 2005, decidir no sentido de uma prorrogação geral do prazo para os países de menor desenvolvimento darem efectividade a todo o Acordo (prorrogação indexada a um limite temporal - 1 de Julho de 2013 -, mas também ao estatuto de 'país menos desenvolvido').

\subsection{Licenças compulsórias}

Embora nos tenhamos proposto abordar unicamente pontos que cabem na 'parte geral' do Acordo, não podemos deixar de referir, enquanto meio de flexibilização das suas disposições, a matéria das licenças compulsórias. Embora inserida no campo particular do direito das marcas (artigo 21. ${ }^{\circ}$, que permite expressamente que os Estados renunciem à concessão de licenças compulsórias) e do direito das patentes (artigo 31. ${ }^{\circ}$ ), é de todo o interesse que esta questão, pela sua relevância, seja aqui tratada.

O recurso a uma licença compulsória reconduz-se, nos termos do artigo 31. do TRIPS, a um "uso sem autorização do titular". Ou seja, trata-se de um acto administrativo ou de uma decisão judicial que atribui ao interessado, em circunstâncias consideradas excepcionais e sem o consentimento

129 Cfr., nomeadamente, Bossche, Peter Van Den, ob. cit., p. 803. 
do proprietário do direito, o exercício de faculdades jurídicas ligadas à titularidade do DPI ${ }^{130}$. Está aqui em causa uma relação jurídica constituída pela força do 'ius imperium', que se opõe à faculdade de o titular do direito, voluntariamente, atribuir licenças de utilização, neste caso, da sua marca ou da sua patente.

De facto, e invocando o disposto nos preceitos acima referidos, o TRIPS admite a concessão destas licenças, o que, à partida, se consubstancia num mecanismo de limitação dos poderes por natureza atribuídos aos titulares de DPI (os mais resistentes à sua concessão vêem-nas como geradoras de um efeito expropriatório sobre os direitos dos titulares). Vejamos se assim é, de facto.

Desde logo, é importante dizer que a atribuição destas autorizações não deixa de estar submetida às finalidades e parâmetros gerais de todo o Acordo, que elegem como objectivo de primeira linha a protecção dos DPI, a limitar toda a interpretação que se possa fazer das disposições do TRIPS. Neste sentido, escreve Remédio MARQues ${ }^{131}$, "o Governo, nos termos do art. $7 .^{\circ}$ do Acordo TRIPS, e tendo em vista o disposto no parágrafo $4 .^{\circ}$ do Preâmbulo deste Acordo, não pode conceder licenças compulsórias se os direitos do criador ou titular forem atingidos sem que ocorra um benefício qualitativamente superior para os interesses gerais e colectivos da comunidade."

Depois, não podem deixar de se referir os inúmeros condicionalismos a que, nos termos do artigo 31. ${ }^{\circ}$, e em matéria de patentes, está sujeita a concessão de uma licença

${ }^{130}$ Quanto à definição do conceito, ver, nomeadamente, MATTHEWs, Duncan, Lessons from negotiating an amendment to the TRIPS Agreement, p. 223: "A compulsory licence is a licence granted by the competent national authority to allow a third party to manufacture a patented product without the authorisation of the right holder."

131 Direito de Autor e Licença Compulsória, p. 73. 
compulsória. Focamos apenas os aspectos que, nessa enumeração exaustiva, nos parecem merecer destaque.

De acordo com o previsto na alínea b) do preceito, exige-se que o interessado na obtenção da licença compulsória tenha desenvolvido esforços no sentido de obter essa autorização de forma voluntária (os desvios a esta regra apenas são admitidos num contexto de emergência nacional ou noutras situações de extrema urgência). Só depois de se verificar um fracasso das negociações entre o interessado e o titular do direito é que pode ser desencadeado o processo de atribuição coerciva da licença. Ora, embora não seja de maior relevo em termos práticos, esta disposição vem reafirmar a supremacia da vontade do titular dos DPI, que é ouvida mesmo quando em causa estão interesses que a ela se sobrepõem. Esta opção ganha mais sentido se considerarmos que, se negociar em condições de liberdade, o detentor da patente poderá ambicionar receber uma remuneração mais elevada pela exploração que autoriza, em vez de ficar sujeito a um preço fixado administrativa ou judicialmente, que sempre ficará aquém das suas pretensões. Esta previsão serve a ideia de que "a intervenção da autoridade pública competente na prolação de uma licença desta natureza terá que ser necessária e adequada a satisfazer as finalidades a que se destina, causando o mínimo de ingerência possível, qualitativa e quantitativamente, no exercício das faculdades jurídicas do titular do direito" ${ }^{132}$.

Por outro lado, note-se que o uso permitido ao licenciado se faz em termos não exclusivos (alínea d)). Esta condicionante acaba por limitar as potenciais vantagens que ele poderia esperar obter no caso de a licença afastar eventuais concorrentes ${ }^{133}$. Mais uma vez se salvaguardam os interesses

132 Marques, Remédio, Direito de Autor e Licença Compulsória, p. 76.

133 A este propósito leia-se em Marques, Remédio, Direito de Autor e Licença Compulsória, p. 85: "esta solução (...) apresenta alguns riscos empresariais para o beneficiário da licença compulsória, o qual pode 
do titular do DPI, que mantém na sua esfera poderes que lhe permitem promover uma estratégia comercial contra os beneficiários de licenças compulsórias (emitindo licenças voluntariamente, como forma de produzir uma 'pressão concorrencial').

Por último, referimos ainda, no contexto da lista de condicionalismos fixada no artigo $31 .^{\circ}$, os poderes de vigilância e controlo confiados à entidade que emite a licença, o que acaba por deixar o licenciado numa situação de maior vulnerabilidade e incerteza. Nos termos da alínea g), a licença pode ser revogada administrativa ou judicialmente, sendo que essa revogação se impõe inelutavelmente ao licenciado, desprovido de qualquer 'poder negocial'. De acordo com Remédio Marques ${ }^{134}$, "o beneficiário de uma licença desta natureza [está sujeito ao] respeito das condições estabelecidas pela entidade administrativa competente ou pelo juiz, à luz do fim que presidiu à sua constituição".

Além destas limitações, evidenciadas na letra da lei, é de notar que, na prática, o recurso a licenças compulsórias foi fortemente restringido por pressões comerciais oriundas das potências económicas ${ }^{135}$ (que têm interesse na manutenção de posições monopolísticas quanto ao fabrico de produtos patenteados), bem como por 'alianças' negociais impostas com recurso a cláusulas TRIPS-plus ${ }^{136}$.

ser surpreendido com a concorrência de um outro beneficiário de uma licença voluntária ou do próprio criador ou titular do direito de autor."

134 Direito de Autor e Licença Compulsória, p. 70.

135 Cfr. Trebilcock, Michael e Howse, Robert, ob. cit., p. 429: "Despite this flexibility..., drug industry interests and some developedcountry governments tried to intimidate developing countries who sought to use this flexibility to address the health crisis of HIV/AIDS."

${ }^{136}$ Veja-se, a este propósito KUANPOTH, Jakkrit, ob. cit., p. 83: "Limiting the right of a country to use compulsory licensing is probably the most significant of the countries under United States FTAs. The TRIPS-plus 
Consideramos que este contexto, de negação do potencial das licenças compulsórias sobre o bem-estar dos consumidores, fomenta o recurso a práticas concorrenciais abusivas por parte dos titulares das patentes, que ficam em condições de exercer pressões inflacionistas sobre os preços. Recusar as licenças compulsórias é, ainda, forçar as importações de produtos que podiam ser produzidos localmente (quando em causa esteja uma licença de produção local, que se contrapõe à licença de livre importação), reforçando o poderio económico das grandes empresas exportadoras ${ }^{137}$. Além de que a utilização deste mecanismo não se pode considerar violador dos DPI, na medida em que ele não envolve uma perda de direito para o titular, mas tão-só uma limitação da propriedade por interesses de ordem pública.

Porém, mais uma vez, não podemos deixar de notar os avanços que, nesta matéria, se fizeram sentir por efeito da Declaração de Doha sobre o TRIPS e a Saúde Pública, adoptada a 14 de Novembro de 2001, no âmbito da Doha Round (parágrafo 6). É nesse momento que se reconhece

rules attempt to make the compulsory licensing provisions difficult to apply, as they set more stringent conditions than the TRIPS standards."

Veja-se também Barbosa, Denis Borges, A nova regulamentação da licença compulsória por interesse público, p. 12: "Não obstante a clareza do mandato de TRIPS, quando se suscitou pela primeira vez a hipótese de concessão de uma licença compulsória de interesse público no Brasil, a reacção dos Estados Unidos fez deflagrar um procedimento contencioso na OMC."

${ }_{137}$ Neste sentido, Brunner, Adriana Gomes, As patentes farmacêuticas e a licença compulsória, p. 30: "No caso das patentes farmacêuticas, essa questão é ainda mais grave diante do indiscutível interesse público em torno da saúde. Admitir a importação, nesse caso, seria aceitar o monopólio injustificável nas mãos das empresas multinacionais, com o considerável aumento de preços dos produtos vedando a livre concorrência e a transferência da tecnologia necessária ao desenvolvimento económico equitativo das nações." 
que as disposições do Acordo TRIPS devem ser usadas no sentido de atender à gravidade dos problemas de saúde pública que afectam os países em desenvolvimento ${ }^{138}$ - assim se legitima o uso de licenças compulsórias. Este reconhecimento deve-se, em muito, à presença de ONG's no processo de negociações, que actuam no sentido de dar voz aos interesses do mundo menos desenvolvido ${ }^{139}$.

No entanto, há quem veja pouca operacionalidade na simplificação do processo de concessão de licenças compulsórias $^{140}$.

138 Neste sentido, Matthews, Duncan, ob. cit., p. 225: “The Declaration recognised the flexibilities contained in the TRIPS Agreement with respect to the right to Grant compulsory licences and the freedom to determine the grounds upon which such licences are granted."

Veja-se também KuANPOTH, Jakkrit, ob. cit., p. 83: "In practice, the countries that intend using compulsory licensing have always been under considerable economic pressure. With the adoption of the Doha Declaration on TRIPS and Public Health, it now seems obvious that WTO Members can legitimately employ this legal mechanism to improve access to medicines."

Leia-se ainda BArbosA, Denis Borges, ob. cit., p. 13: "Seguindo a explicação oficial da OMC, nesta declaração os ministros enfatizam que é importante executar e interpretar o Acordo TRIPS de maneira que dê apoio aos objectivos da saúde pública, promovendo acesso aos medicamentos existentes e a criação de medicamentos novos. $\mathrm{O}$ enunciado afirma que o Acordo TRIPS não deve impedir que os governos nacionais ajam para proteger a saúde pública, pois que têm eles o direito de usar as flexibilidades do acordo."

139 Cfr. MatThews, Duncan, ob. cit., p. 226: "As during the earlier negotiations on the TRIPS Agreement, the US and European Communities took the lead. However, unlike the original TRIPS negotiations, the Paragraph 6 process was also market by a far greater degree of involvement on the part of Non-Governmental Organisations (NGOs), acting in support of the developing country cause."

${ }^{140}$ Veja-se, a este propósito, Carvalho, Nuno Pires, The TRIPS Regime of Patent Rights, p. 241: "The fact is that problema mentioned in paragraph 6 of the Doha Declaration is a very theoretical one, if not 


\title{
3.4. Cooperação técnica
}

\author{
Embora dotada de relevo teórico, cremos que esta pre- \\ visão ${ }^{141}$ se consubstancia numa mera norma programática, na
}

purely academic. The major - if not the only - obstacle to granting compulsory licenses in developing countries is the lack of technology necessary to copy the patented product, not a lack of economies of scale or administrative barriers. Therefore, the countries that are most likely to be able to participate actively in the practical implementation of paragraph 6 are those countries that possess such technology, and those are a very few developed countries, where production costs are very high and therefore the prices of drugs are prohibitively expensive for poor countries."

De facto, não podemos deixar se reconhecer a legitimidade desta posição. O parágrafo $6 .^{\circ}$ da Declaração de Doha, reconhecendo a insuficiência da estrutura empresarial de muitos países em desenvolvimento, vem admitir que reafirmar a possibilidade de recurso a licenças compulsórias poderá ter poucos efeitos práticos. No entanto, a Declaração não apresenta uma solução para o problema que identifica; ao invés, deixa-o nas mãos do Conselho Geral. Este órgão, com a Decisão de 30 de Agosto de 2003 (disponível em http://www.wto.org/english/tratop_e/trips_e/ implem_para6_e.htm), vem reforçar a ideia de cooperação técnica entre os países com distintos níveis de desenvolvimento, admitindo que os produtos produzidos sob licença compulsória possam ser exportados por países sem capacidade para os produzir. Nesta decisão encontramos, portanto, um significativo efeito prático.

${ }^{141}$ Convocamos, para este ponto, o disposto nos artigos 66.2 e 67 do Acordo:

“[66.2.] Os países desenvolvidos Membros concederão incentivos a empresas e instituições de seus territórios com o objetivo de promover e estimular a transferência de tecnologia aos países de menor desenvolvimento relativo Membros, a fim de habilitá-los a estabelecer uma base tecnológica sólida e viável.

Artigo 67 Cooperação Técnica

A fim de facilitar a aplicação do presente Acordo, os países desenvolvidos Membros, a pedido, e em termos e condições mutuamente acordadas, prestarão cooperação técnica e financeira aos países em desenvolvimento Membros e de menor desenvolvimento relativo Membros. 
medida que não sugere qualquer mecanismo susceptível de a pôr em prática. De facto, o TRIPS não prevê uma estrutura organizada no sentido de assegurar o cumprimento desta obrigação de cooperação. Como escreve Alberto Francisco Almeida (ob. cit., p. 53), "o art. 66. ${ }^{\circ}, n .{ }^{\circ} 2$, não estabelece uma obrigação concreta, mas uma mera intenção" ${ }^{142}$.

Este acaba por ser um reconhecimento indirecto, por parte das potências económicas promotoras do Acordo, de que ele é realmente desvantajoso para os países com baixos níveis de desenvolvimento.

$\mathrm{E}$, de certa forma, não podemos deixar de ver aqui outra forma de atender aos interesses económicos dos Estados mais desenvolvidos, na medida em que a assistência eventualmente prestada se traduzirá, afinal, num meio de garantir a eficácia do Acordo ${ }^{143}$. É que a cooperação técnica acaba por ser conduzida pelos mesmos interesses que dominaram as negociações.

No mínimo, é legítimo que se levantem dúvidas sobre os reais resultados a que pode conduzir esta 'cooperação'.

Essa cooperação incluirá assistência na elaboração de leis e regulamentos sobre protecção e aplicação de normas de protecção dos direitos de propriedade intelectual bem como sobre a prevenção de seu abuso, e incluirá apoio ao estabelecimento e fortalecimento dos escritórios e agências nacionais competentes nesses assuntos, inclusive na formação de pessoal."

${ }^{142}$ Como ilustra Finger, J. Michael, Implementing the Uruguay Round Agreements, p. 1102: "Developing countries accepted bound commitments to implement, they received in exchange unbound promises of assistance to do so."

143 Neste sentido, veja-se United Nations, The TRIPS Agreement and Developing Countries, p. 4: "It is evident that the primary and immediate beneficiaries of the implementation of the TRIPS are likely to be technology and information developers in the industrialized countries. (...) It is therefore not unreasonable to remind industrialized countries that it is in their own interest to assist developing countries in their efforts to implement the Agreement through technical and financial support, as stipulated in the Agreement." 
$\mathrm{Na}$ verdade, tratar-se-á de um percurso de solidariedade para com os países em desenvolvimento, ou acabará por se traduzir num mecanismo de cooperação das grandes potências consigo próprias (ou com os grupos empresariais que representam $)^{144}$ ? Não podemos concordar com os mais optimistas, que dirão que esta se trata de uma solução conciliatória $^{145}$.

A verdade é que até os custos mais imediatos do Acordo pesam em desfavor das nações menos desenvolvidas, que, com sistemas jurídicos e económicos mais precários, se vêm obrigadas a fazer grandes esforços de adaptação a estes novos parâmetros impostos pelo TRIPS ${ }^{146}$. São-lhes exigidas, sobretudo, reformas do sistema legal, administrativo e judicial, bem como políticas de natureza económica ${ }^{147}$.

144 De acordo com Dutfield, Graham e Suthersanen, Uma, ob. cit., p. 40: "The provision of intellectual property technical assistance by international organizations, developed country governmental agencies, intellectual property offices and business and law associations has become quite controversial. Such assistance often seeks to promote standards of intellectual property protection offices higher than those required by TRIPS in order to protect the interests of providers and funders."

145 Entre outros, Reichman, Jerome, ob. cit., p. 133: "If developed and developing countries can learn to cooperate with each other during the delicate, post-transitional phase of the TRIPs Agreement, they may jointly preside over a new epoch of investment and technological innovation."

${ }^{146}$ Veja-se o exemplo dado por Mota, Pedro Infante, ob. cit., p. 498: “o México gastou cerca de 30 milhões de dólares norte-americanos no reforço da sua legislação nacional em matéria de propriedade intelectual, que era já de si bem mais exigente que a legislação vigente na grande maioria dos países menos avançados, valor esse que corresponde a cerca de $20 \%$ de um ano de orçamento para o desenvolvimento em alguns países menos avançados."

147 Neste sentido, United Nations, ob. cit., p. 20: “...the administrative requirements with which developing countries must cope include: (a) improving the relevant legal framework in line with the general obligations of the Agreement; (b) strengthening or establishing the relevant administrative offices; (c) enhancing enforcement mechanisms of 
Não podemos deixar de considerar que os gastos com a implementação do TRIPS, no caso dos países pobres, representam uma afectação de receita que poderia ter sido canalizada para a satisfação de necessidades mais prementes - se é verdade que a notória escassez de recursos exige uma rígida hierarquização de prioridades!

Consciente de que pouca efectividade tinha sido dada a esta disposição, o Conselho do TRIPS vem tomar uma decisão, em 19 de Fevereiro de 2003, nos termos da qual os países desenvolvidos devem apresentar, anualmente, relatórios das acções postas em prática ou planeadas, no sentido de executar os seus compromissos no âmbito do artigo $66 .^{\circ}$, n. ${ }^{\circ} 2$ e $67 .^{0148}$.

\section{Considerações finais}

De acordo com Alberto Francisco Almeida (ob. cit., p. 43), "a conclusão do acordo TRIP's permitiu as conquistas dos

the relevant laws and regulations; (d) increasing training; and (e) increasing the capability to monitor transfer of technology arrangements within and between enterprises, along with ensuring that competition authorities are knowledgeable about potential IPR abuses.

Veja-se também Hoekman, Bernard e Kostecki, Michel, ob. cit., p. 290: "Implementation of the TRIPs agreement will involve substantial adjustments and costs for developing countries. These costs are of two types. First, bringing legislation into conformity and strengthening the domestic institutions that will be charged with enforcing the new laws costs money. (...) Second, there are economic costs, especially in the short run, insofar as rents are transferred from domestic consumers to foreign holders of IPRs."

148 Cfr. Bossche, PeterVan Den, ob. cit., p. 804.

Veja-se também Almeida, Alberto Francisco Ribeiro, ob. cit., p. 86: "determina-se que os países desenvolvidos deverão fazer prova detalhada dos incentivos concedidos às empresas e instituições do seu território destinados a estimular a transferência de tecnologia para os países menos desenvolvidos, nos termos do art. 66. ${ }^{\circ}$, n. $^{\circ} 2 . "$ 
países industrializados (que de facto conseguiram neste acordo espethar, quase integralmente, a sua concepção de propriedade intelectual ao serviço de certos valores e interesses) e a cedência dos países em vias de desenvolvimento."

Há quem, todavia, veja no TRIPS uma estrutura normativa com significativo grau de flexibilidade, que os países em desenvolvimento podem usar a seu favor ${ }^{149}$. Não cremos, contudo, que os potenciais mecanismos de flexibilidade, teoricamente apresentados, tragam resultados práticos positivos, na medida em que o seu efectivo sucesso está muito mais dependente de condições económicas e forças políticas do que de abstractas consagrações legislativas ${ }^{150}$.

É que, se nos quisermos desprender de construções teóricas, os resultados práticos da implementação deste Acordo só nos podem conduzir a uma conclusão: os países em desenvolvimento são os efectivos perdedores ${ }^{151}$.

149 A título de exemplo, Gervais, Daniel, Intellectual Property, Trade and Development, p. 4: "TRIPS is not perfect, of course, but there is a significant degree of built in-policy flexibility that developing economies can use."

No mesmo sentido, Panagariya, Arvind, ob. cit., p. 1221: "While the balance of benefits was in favour of developed countries reflecting their greater bargaining power, developing countries made significant gains as well." Este autor assume que os países em desenvolvimento podem perspectivar os custos do Acordo como benefícios, assumindo-o como um veículo para a liberalização comercial, e como uma via de estabelecer a igualdade entre todos os países nesta matéria (no quadro do multilateralismo). Acaba dizendo que o fracasso com que alguns países e entidades não governamentais rotulam o Acordo se deve, em parte, ao excesso de expectativas (irreais) que geraram em relação a ele!

${ }^{150}$ Seguimos quanto a este ponto, o entendimento consagrado, por exemplo, em Dutfield, Graham, Knowledge diplomacy and the new intellectual property fundamentalism, p. 31: "In theory, the flexibilities of the World Trade Organization-administered TRIPS Agreement should provide developing countries with ample opportunities (...). Despite this, developing country freedom to exploit these opportunities is diminishing rapidly."

151 Cfr., nomeadamente, Finger, J. Michael, ob. cit., p. 1103: "The developing countries for which we have comparable data will lose as 
E o alerta que aqui deixamos é que o liberalismo económico propugnado pela OMC (e muito menos a defesa dos direitos de propriedade intelectual) não deve constituir um fim em si mesmo ${ }^{152}$, mas antes uma forma de colocar a economia ao serviço dos superiores interesses da humanidade ${ }^{153}$.

\subsection{Notas conclusivas}

Reconhecendo as dificuldades em estabelecer regras sobre propriedade industrial que sejam globalmente justas, porque o nível de desenvolvimento dos vários países requer diferentes abordagens, parece-nos que teria sido melhor adiar

much or more from TRIPS as they gain from the market access agreement on manufactures including MFA elimination. The US on the other hand will gain enormously from TRIPS, 7.5 times as much as from all countries' liberalization on imports of manufactures, including its own liberalization."

152 Petersmann, Ernest-Ulrich, ob. cit., p. 41: "WTO governments should take into account the numerous interrelationships between human rights, national constitutions and international guarantees of freedom of trade and non-discrimination." Defende este autor a consideração dos direitos humanos no quadro da OMC, como forma de obter uma legitimidade moral, constitucional e política que vá além das motivações económicas utilitaristas.

No entanto, cremos que a maior integração de competências por parte da OMC, proposta por Petersmann, pode importar riscos, como sejam o acentuar dos problemas que aqui fomos enunciando.

153 Para ilustrar esta ideia, veja-se Ferreira, Eduardo Paz, Valores e Interesses, p. 41: "Empenharmo-nos na tarefa de desenvolvimento económico é uma opção que não se justifica apenas por um objectivo de ver aumentar a riqueza de certos países, mas antes pela esperança de melhorar a vida das suas populações, reduzindo o número de pobres, eliminando a fome e criando uma esperança de vida melhor - de uma vida digna de ser vivida - para milhões de crianças às quais não é sequer dada hoje a garantia de que vão crescer e ter uma vida adulta." 
a celebração de mais um acordo sobre o tema, dando prioridade a questões que permitam aos Estados concorrer em condições mais iguais.

A verdade é que a harmonização de regras e padrões de comportamento só se torna viável se estiverem também harmonizados os níveis de desenvolvimento, pelo que, também nesta matéria, talvez se mostrasse mais adequada a máxima de 'discriminar para igualizar'. Até porque este Acordo pouco considera os limites que devem ser impostos, no sentido de impedir a apropriação e o controlo (baseado em posições monopolistas), por parte de grandes multinacionais, do conhecimento imprescindível para o desenvolvimento das sociedades actuais.

De facto, vemos fundamentada a suspeita de que, com o TRIPS, acaba por se restringir ainda mais o potencial de competitividade dos países menos desenvolvidos e a capacidade de o comércio internacional se realizar em condições de igualdade, na medida em que se globaliza um modelo de protecção de DPI desconsiderando a especificidade de cada contexto. Ou seja, procura-se proteger um determinado estádio de desenvolvimento, a que alguns países chegaram, mas do qual outros ainda se encontram muito longe.

A exposição que fizemos deixa-nos pistas no sentido de que, sob a capa do liberalismo, o TRIPS pode revelar-se um reflexo do proteccionismo dissimulado, que apenas interessa aos países com efectiva capacidade de orientação da política económica internacional. Ainda que assente numa estrutura liberal, a verdade é que o TRIPS tem sido conduzido no sentido de proteger algumas economias, não tanto face aos países mais pobres, mas principalmente face aos novos países em industrialização da Ásia e da América Latina, com capacidade exportadora e um mercado interno pujante (e que, por isso, se podem revelar uma 'ameaça' aos poderes económicos instituídos). 
$\mathrm{Na}$ verdade, não nos parece que este Acordo se concilie com a política do livre comércio propugnada pela OMC, desde logo, porque legitima a imposição de efectivas barreiras comerciais. Por outro lado, e apesar do desenvolvimento económico não ser objectivo imediato da OMC, ele tem vindo a ser considerado (pelo menos teoricamente) nas negociações levadas a cabo no âmbito desta organização, ao ponto de se identificar, como orientador da sua actividade, um princípio de tratamento especial e diferenciado aos países menos desenvolvidos. No entanto, somos levados a considerar o TRIPS como o expoente da falta de concretização deste princípio.

Se nos focarmos nos desenvolvimentos que se têm verificado, o nosso entendimento não se altera substancialmente. É certo que não podemos deixar de assumir a Declaração de Doha (sobre o TRIPS e a saúde pública), enquanto acordo interpretativo, como um reconhecimento do fracasso do TRIPS, num momento em que temos grupos da sociedade civil a insurgirem-se contra o desequilíbrio gerado pelo Acordo - é o momento em que os países concordam em rever aquilo que negociaram e reafirmam a primazia da saúde sobre os interesses comerciais. De facto, os objectivos de Doha parecem muito mais vocacionados para servir os interesses dos países em desenvolvimento do que dos países desenvolvidos. No entanto, os seus resultados nunca acabam por anular as injustiças consagradas no Acordo - se houvesse uma subversão do regime, ele deixaria de fazer sentido.

Apesar de este documento consubstanciar, a nosso ver, uma proclamação daqueles que são os problemas do mundo menos desenvolvido, não chegam a ser definidas políticas concretas, que deveriam alicerçar-se em cedências por parte das grandes potências promotoras do Acordo. 


\section{BIBLIOGRAFIA}

Adiers, Cláudia Marins, Importações paralelas e seus reflexos no direito contratual e concorrencial, Revista da Associação Brasileira da Propriedade Intelectual, volume 64, Maio/Junho 2003.

Almeida, Alberto Francisco Ribeiro, Os princípios estruturantes do Acordo TRIP's, Boletim de Ciências Económicas, Volume XLVII (47), Faculdade de Direito da Universidade de Coimbra, 2004.

Álvares, Pedro, O GATT (de Punta del Este a Marraquexe), Publicações Europa-América, 1994.

BArbosa, Denis Borges, A nova regulamentação da licença compulsória por interesse público, Revista da Associação Brasileira da Propriedade Intelectual, volume 67, Nov/Dez de 2003.

Bossche, Peter Van Den, The Law and Policy of the World Trade Organization, 2. ${ }^{a}$ edição, Cambridge University Press, 2008.

Brunner, Adriana Gomes, As patentes farmacêuticas e a licença compulsória: o fim de uma batalha entre os Estados Unidos e o Brasil, Revista da Associação Brasileira da Propriedade Intelectual, volume 55, Nov/Dez de 2001.

Canotilho, J.J. Gomes; Machado, Jónatas, A questão da Constitucionalidade das Patentes "Pipeline" à luz da Constituição Federal Brasileira de 1988, Almedina, 2008.

Carvalho, Paula, A Violação da Licença e o Esgotamento do Direito de Marca, Coimbra Editora, 2011.

Carvalho, Nuno Pires, The TRIPS Regime of Patent Rights, Wolters Kluwer, 3. ${ }^{a}$ ed., 2010.

-, The TRIPS Regime of Antitrust and Undisclosed Information, Wolters Kluwer, 2008.

Dutfield, Graham, Knowledge diplomacy and the new intelellectual property fundamentalism, in Malbon, Justin; Lawson, Charles (ed.), Interpreting and implementing the TRIPS Agreement - Is it fair?, Edward Elgar Publishing, UK, 2008.

-, Suthersanen, Uma, Global Intellectual Property Law, Edward Elgar Publishing, UK, 2008.

EInHORN, Talia, The impact of the WTO Agreement on TRIPS (Trade-Related Aspects of Intellectual Property Rights) on EC Law: a challenge to regionalism, Common Market Law Review,Vol. 35, n. ${ }^{\circ}$ 5, Kluwer Law International, October 1998.

Ferreira, Eduardo Paz, Valores e Interesses - Desenvolvimento Económico e Política Económica de Cooperação, Almedina, 2004.

Foster, Neil, Intellectual property rights and the margins of international trade, The Journal of International Trade \& Economic Development: 
An International and Comparative Review, DOI:10.1080/09638199.2 012.664556. (versão online).

FInger, J. Michael, Implementing the Uruguai Roud Agreements: Problems for Developing Countries, in Peter Lloyd; Chris Milner (ed.), The World Economy - Global Trade Policy 2001, volume 24, number 9, Oxford, September 2001.

GAD, Mohamed, TRIPS Dispute Settlement and Developing Country Interests, in Correa, Carlos M.; Yusuf, Abdulqawi, Intellectual Property and International Trade - The TRIPS Agreement, Wolters Kluwer, $2 .{ }^{2}$ edição, 2008.

Gervais, Daniel, Intellectual Property, Trade and Development: strategies to optimize economic development in a TRIPS-Plus Era, Oxford University Press, Oxford, 2007.

-, The TRIPS Agreement - Drafting History and Analysis, 3. ${ }^{\mathrm{a}}$ ed., Sweet \& Maxwell, 2008.

GONÇALVES, Luís Couto, A protecção da propriedade industrial (introdução ao sistema internacional e europeu), Estudos em homenagem ao Prof. Doutor Jorge de Figueiredo Dias, Volume IV, Boletim da Faculdade de Direito da Universidade de Coimbra, Coimbra Editora, 2010.

GiBson, Johanna, Knowlegde and other values - Intellectual property and the limitations for traditional knowledge, in Westkamp, Guido (ed.), Emerging Issues in Intellectual Property, Queen Mary Intellectual Property Research Institute, University of London, UK, 2007.

Hase, Andres, The application and interpretation of the Agreement, in Correa, Carlos M.; Yusuf, Abdulqawi, Intellectual Property and International Trade - The TRIPS Agreement, Wolters Kluwer, 2. ${ }^{\text {a }}$ edição, 2008

Hoenman, Bernard; Kostecki, Michel, The Political Economy of the World Trading System (The WTO and Beyond), 2. ${ }^{a}$ edição, Oxford University Press, 2001.

KuANPOTH, Jakkrit, Intellectual property protection after TRIPS: An Asian experience, in Malbon, Justin; Lawson, Charles (ed.), Interpreting and implementing the TRIPS Agreement - Is it fair?, Edward Elgar Publishing, UK, 2008.

Leme, Letícia Frazão Alexandre de Moraes, O tratamento especial e diferenciado dos países em desenvolvimento. Do GATT à OMC, Fundação Alexandre de Gusmão, Brasília, 2011.

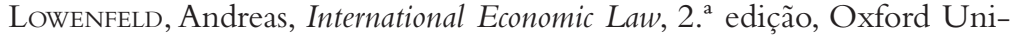
versity Press, 2008.

Marques, J.P. Remédio, Direito de Autor e Licença Compulsória - um olhar luso-brasileiro, Separata do Boletim da Faculdade de Direito, volume LXXXVI, Universidade de Coimbra, 2010. 
-, A patenteabilidade de substâncias químicas e farmacêuticas de selecção e de métodos de terapia, no domínio do CPI de 1940 - A (dis) simulação de reivindicações de processo e a entrada em vigor do CPI, de 1995, e do Acordo TRIPS, in Temas de Direito Comercial, Cadernos "O Direito", n. ${ }^{\circ} 4$, Almedina, 2009.

-, Propriedade intelectual: tendências globais, em Boletim da Faculdade de Direito, Vol. LXXXIV [Separata], Coimbra, 2008.

Maskus, Keith, Benefiting from intellectual property protection, in Hoekman, Bernard; Matoo, Aaditya; English, Philip (ed.), Development, Trade and the WTO - a handbook, The World Bank Washington, 2002.

Matthews, Duncan, Lessons from negotiating an amendment to the TRIPS Agreement, in Westkamp, Guido (ed.), Emerging Issues in Intellectual Property, Queen Mary Intellectual Property Research Institute, University of London, UK, 2007.

Mota, Pedro Infante, O sistema GATT/OMC: introdução histórica e princípios fundamentais, Almedina, Coimbra, 2005.

Nguyen, Tu Thanh, Competition Law, Technology Transfer and the TRIPS Agreement - implications for developing countries, Northampton : Edward Elgar, 2010.

Olavo, Carlos, Importações Paralelas e Esgotamento de Direitos de Propriedade Industrial: Questões e Perspectivas, Revista da Ordem dos Advogados, Ano 61, Lisboa, 2001.

PAIS, Sofia Oliveira, Proibição de importações paralelas e justificação objectiva no direito da concorrência da União Europeia, Estudos em memória do Prof. Doutor J.L. Saldanha Sanches, volume I, Coimbra Editora, 2011.

Panagariya, Arvind, Developing Countries at Doha: A Political Economy Analysis, in Peter Lloyd; Chris Milner (ed.), The World Economy - Global Trade Policy 2002, volume 25, number 9, Oxford, September 2002.

Pereira, Alexandre Dias, A Revisão do Acordo ADPIC/TRIPS (Alguns Tópicos), in Direito da Sociedade da Informação - separata do volume VI, Associação Portuguesa da Sociedade da Informação, Coimbra Editora, 2006.

Petersmann, Ernest-Ulrich, From Negative to Positive Integration in the WTO, in Cottier, Thomas; Mavroidis, Petros (ed.), Intellectual Property - trade, competition and sustainable development, Studies in International Economics, The World Trade Forum, Volume 3, Michigan.

Reichman, Jerome, The TRIPs Agreement Comes of Age: Conflict or Cooperation in the Post-Transitional Phase?, in Cottier, Thomas; 
Mavroidis, Petros (ed.), Intellectual Property - trade, competition and sustainable development, Studies in International Economics, The World Trade Forum, Volume 3, Michigan.

Silva, Pedro Sousa e, Direito Comunitário e Propriedade Industrial - o princípio do esgotamento dos direitos, Dissertação de Mestrado em Ciências Jurídico-Empresariais da Faculdade de Direito da Universidade de Coimbra, Janeiro de 1991.

-, Direito Industrial: noções fundamentais, Coimbra Editora, grupo Wolters Kluwer, 1. ${ }^{\text {a }}$ edição, Coimbra, 2011.

Scholze, Simone H. C., Fabricação local, licença compulsória e importação paralela na lei de propriedade industrial, Revista da Associação Brasileira da Propriedade Intelectual, n. ${ }^{\circ}$ 54, Set/Out de 2001.

Subramanian, Arvind, Proprietary Protection of the Genetic Resources and Traditional Knowledge, in Hoekman, Bernard; Matoo, Aaditya; English, Philip (ed.), Development, Trade and the WTO - a handbook, The World Bank Washington, 2002.

Trebilcock, Michael e HOWSE, Robert, The Regulation of International Trade, 3. ${ }^{a}$ edição, Routledge - Taylor \& Francis Group, 2005.

UNCTAD-ICTSD on IPRs and Sustainable Development, Resource Book on TRIPS and development, Cambridge University Press, 2005.

United Nations Conference on Trade and Development (secretaRIAT), The TRIPS Agreement and Developing Countries, New York and Geneva, 1996.

Vicente, Dário Moura, A Tutela Internacional da Propriedade Intelectual, Almedina, 2008.

WATAL, Jayashree, Implementing the TRIPS Agreement, in Hoekman, Bernard; Matoo, Aaditya; English, Philip (ed.), Development, Trade and the WTO - a handbook, The World Bank Washington, 2002.

YI-ChOng, Xu, Last chance? Multilateralism, TRIPS and developing countries, in Malbon, Justin; Lawson, Charles (ed.), Interpreting and implementing the TRIPS Agreement - Is it fair?, Edward Elgar Publishing, UK, 2008.

Yusuf, Abdulqawi, TRIPS: Backgroud, Principles and General Provisions, in Correa, Carlos M.; Yusuf, Abdulqawi, Intellectual Property and International Trade - The TRIPS Agreement, Wolters Kluwer, 2. edição, 2008. 
Resumo: O artigo avalia as razões que determinaram a celebração do Agreement on Trade-Related Aspects of Intellectual Property Rights (TRIPS), considerando o texto final como retrato de uma ideologia, de tensões políticas, de motivações económicas. Procura-se averiguar até que ponto este Acordo está ainda ao serviço dos valores fundamentais que orientam a actividade da Organização Mundial do Comércio (OMC).

Depois de se dissecarem os pressupostos que definem o contexto em que o TRIPS foi celebrado, são consideradas as implicações que ele produziu na comunidade internacional. Convocam-se, para esta análise, apenas as normas que, caindo na parte geral do Acordo, constituem um 'espelho' dos interesses conflituantes que lhe estão subjacentes.

Por conseguinte, excluem-se deste estudo as disposições especiais que cabem dentro do âmbito particular de cada categoria de Direitos de Propriedade Intelectual (DPI), bem como algumas normas sem carácter inovador (porque não suscitam particular discussão ou se limitam a seguir o rumo traçado por convenções anteriores sobre a matéria) ou sem relevância ao nível da representação dos custos e beneficios que o TRIPS faz transparecer.

O trabalho hermenêutico é dividido em duas partes: confrontando as normas que evidenciam a potencial severidade do TRIPS com aquelas que, à partida, a atenuam. Assim, convocam-se, em primeiro lugar, as disposições que parecem acentuar a rigidez do Acordo, revelando a força imperativa daqueles que o promoveram. Num segundo momento, questiona-se se aquelas regras que têm sido vistas como mecanismos de flexibilização do TRIPS, no sentido de restaurarem o equilíbrio que deve existir entre os interesses das partes contratantes, o são efectivamente.

E não se deixa de fazer referência aos desenvolvimentos pós-TRIPS, considerando para isso os progressos institucionais e as posições doutrinais mais relevantes na matéria.

Palavras-chave: Propriedade Intelectual, Acordo TRIPS, Comércio internacional, Organização Mundial do Comércio, Desenvolvimento económico.

The TRIPS Agreement in the dynamics of international trade

Abstract: The article evaluates the reasons which determined the celebration of the Agreement on Trade-Related Aspects of Intellectual Property Rights (TRIPS) and considers the final text as a portrait of an ideology, 
political tensions, and economic motivations. It seeks also to ascertain whether this Agreement is still at the service of the fundamental values which guide World Trade Organization's (WTO) actions.

After dissecting the reasons that led to the TRIPS Agreement, the implications in the international community are also considered. This analysis only takes up the rules which, being in the general part of the Agreement, constitute a 'mirror' of its underlying conflicting interests.

Thus, from this study are excluded the special provisions that fit within the individual scope of each category of Intellectual Property Rights (IPR) as well as some norms without any innovation (as they don't raise any special discussion or as they tend to follow the path laid down by previous treaties on this issue) or without relevance to the representation of the costs and benefits that the TRIPS allows to become apparent.

The work of interpretation is done in two parts by comparing the rules that show the potential harshness of the TRIPS Agreement with those that a priori mitigate it. The rules that appear to emphasize the harshness of the Agreement are addressed first; they reveal an imperative force of its promoters. In a second moment, it is questioned whether those rules which have been regarded as TRIP's flexible mechanisms are actually flexible and whether they restore the required balance concerning the interests of the contracting parties.

Post-TRIPS developments are also taken into account, namely the institutional progress and the most relevant doctrinal stands on the matter.

Keywords: intellectual property; TRIPS Agreement; international trade; World Trade Organization; economic development.

Marta Coimbra Faculdade de Direito da Universidade de Coimbra (Doutoranda) 